\title{
La biblia en los catecismos (II)
}

\author{
LUIS RESINES \\ Estudio Teológico Agustiniano. Valladolid
}

\section{CONTINUIDAD EN EL SIGLO XIX}

La prolongada ausencia de la biblia como fuente e inspiración en la catequesis no se solventó de la noche a la mañana. He indicado unas líneas más arriba que la modificación de la normativa que venía de Trento, acerca de la lectura y edición de la biblia, se había flexibilizado con nuevas directrices. Sin embargo, esta incipiente apertura, apenas tuvo repercusión en la catequesis: los autores de catecismos seguían anclados en los patrones tradicionales, y acaso hay que afirmar que se ratificaron más en ellos. Esto se debe, sin duda, a la postura marcadamente defensiva que adoptó la Iglesia, y que, con el paso de los años, se acentuó más y más en este siglo. Todo lo que venía de fuera de la Iglesia era visto con recelo, cuando no con hostilidad. La recomendación de defensa a ultranza, y de no hacer concesiones, llevaba a reafirmarse en lo establecido en Trento, incluso sin atender a propuestas como la de una más frecuente lectura y conocimiento bíblicos. La catequesis, reflejo de las tendencias generales en la Iglesia, no constituyó una excepción.

Es imposible recorrer uno por uno los autores de catecismos del XIX, máxime cuando hay que repetir como tendencia obligada los mismos criterios del pasado. Por eso procede fijar la atención, especialmente en los dos autores de catecismos que tuvieron mayor acogida en sus publicaciones, reflejada esta por las numerosas ediciones que se sucedieron.

\subsection{Santiago José García Mazo}

Natural de la sierra de Gredos (Bohoyo), este abulense pasó por diversos cargos hasta llegar a ser magistral en la catedral vallisoletana. 
Como obra de madurez hay que calificar su Catecismo de la doctrina cristiana esplicado, o esplicaciones del Astete, que convienen también al Ripalda, Valladolid, Vda. de Roldán, 1837. Como señala el título, García Mazo hizo un comentario directo al catecismo de Astete; $y$, dada la afinidad de conceptos que tenía el que se conocía como catecismo de Ripalda, -también escrito por Astete- el título indica que tales explicaciones se acomodan igualmente a este otro catecismo, aunque él no llevó a cabo ninguna recomendación, adaptación o síntesis entre ambos catecismos.

Lo que hay que afirmar, sin género de duda, es que García Mazo acertó a expresar lo que estaba demandando la mentalidad de los católicos de su época. Y con una mentalidad marcadamente cerrada y tradicional, su comentario o explicación alcanzó un éxito que se prolongó, sin exageración, hasta ediciones que se continuaron publicando un siglo después, sin contar las muchas ediciones no legales que se hicieron a sus espaldas ${ }^{46}$. Esto muestra que los católicos se aferraron, repitieron, hicieron suyos y se identificaron con los criterios que Santiago José García Mazo plasmó en su Catecismo.

En materia de incorporación o de empleo de la biblia, es obligado decir que ciertamente la empleó, aunque con tales cortapisas que obligan a matizar mucho la afirmación. Es verdad que en su libro se encuentran referencias bíblicas; pero éstas no son demasiado frecuentes. Por otra parte lo que suele ocurrir es que aparece el texto bíblico, o con más frecuencia, la idea de lo que el texto bíblico dice, pero sin reproducirlo, y remite en nota a pie de página a su localización. En algunas ocasiones consta que transmite ideas o expresiones de la escritura, como cuando indica, por ejemplo: Dice san Pablo, o algo similar... Pero en muchas más ocasiones esto ni siquiera se insinúa, por lo cual el lector podría sospechar que se trata de una cita, pero sin saber cuál era su origen. A esto hay que añadir que utiliza el mismo tipo de alusiones cuando se trata de una afirmación bíblica o de una cita de la Suma Teológica, o un aserto de san Agustín. Es decir, todo tiene la misma validez, porque se trata de reforzar un pensamiento ya expresado, con un texto que lo consolida, sin mayor trascendencia para la palabra de Dios que para la reflexión humana.

${ }^{46}$ L. Resines, «Las ediciones fraudulentas del Catecismo de Mazo», Estudio Agustiniano 40 (2005) 567-575. 
Naturalmente, esto no es un pensamiento bíblico que traspase las páginas del catecismo, ni un criterio que fundamente lo que se afirma. Este tipo de enseñanzas, de marcado corte escolástico y tradicional ya estaba establecido, y no había por qué cambiarlo sin necesidad. Lo que García Mazo pretende es explicarlo, y de vez en cuando un pensamiento bíblico o doctrinal, sea cual sea su origen o autoridad, viene bien para mostrar que se trata de una forma de pensar que tiene sus fundamentos. Ahora bien, estos fundamentos no son punto de partida y manantial del que se surten, sino refuerzos que consolidan lo ya establecido. En esa categoría, la biblia es un apoyo más.

En algún momento se refiere de forma expresa a la escritura, por ejemplo, cuando afirma que «los Apóstoles y Evangelistas escribieron el nuevo Testamento, y en él nos dijeron mucho de lo que enseñó y obró Jesucristo, pero dejaron tanto sin decir...» (p. 21): como se comprueba, no es posible apoyarse en esto para ensalzar su empleo de la biblia. Otro tanto ocurre con el texto en que afirma que «de este modo estamos obligados los cristianos a creer y confesar todo lo que está en la Sagrada Escritura, y cuanto Dios tiene revelado a su Iglesia» (p. 108). Pero una afirmación de esta naturaleza tiene un sentido completamente diferente cuando se conoce lo que dice la escritura, que cuando eso se da por supuesto y se pide un asentimiento incondicional, aunque carente de fundamento, de conocimiento.

Las alusiones a la biblia no pasan de ser un episodio - atinadamente empleado en la mayor parte de las ocasiones - pero que de ninguna manera lleva a entroncar la fe con la palabra de Dios, sino con la síntesis que García Mazo, como otros escritores, ofrece a sus lectores.

\subsection{Antonio María Claret}

Dejo intencionadamente a un lado otros catecismos de Claret, que tuvieron menos importancia y difusión, para centrarme en el que resultó más conocido, el titulado Catecismo de la doctrina cristiana, explicado y adaptado a la capacidad de los niños y adornado con muchas láminas, Barcelona, Her. Vda. de Plá, 1848. El mismo año publicó las dos primeras ediciones catalana y castellana; y ésta segunda se continuó editando durante más de medio siglo, hasta los primeros años del siglo XX, aunque ciertamente con algunos cambios. Más de cincuenta años de vigencia, edición tras edición, no lo tienen en su haber muchos catecismos. Quiere esto decir 
que gozó de una notable aceptación, y que fueron muchos los que se identificaron con sus enseñanzas, y las transmitieron a otras personas.

Respecto al uso de la biblia que hace este Catecismo, con cierta frecuencia aparecen en el texto frases bíblicas (en cualquiera de las dos versiones catalana y castellana), ordinariamente bien aducidas según la materia tratada y con su correspondiente cita. Siempre aparecen en la parte explicativa de cada lección, pero nunca en las preguntas y respuestas que, al final, resumen lo explicado. Esto ya es un dato considerable, porque en más de un caso, lo que llegaba hasta los niños, omitidas las explicaciones, eran las preguntas y respuestas que eran aprendidas de memoria. Supone, por tanto, un notable recorte.

A pesar de que hay un número no desdeñable de frases bíblicas, es mucho más frecuente encontrar páginas enteras en que no aparece ninguna: recurrir a la biblia no es algo raro, pero desde luego no es lo habitual. Cuando echa mano de esas frases bíblicas, las otorga, a los ojos del lector, la misma autoridad que concede a otras fuentes que cita igualmente (por ejemplo, Dionisio Areopagita, Rousseau, Melchor Cano, concilio de Trento,...) lo que supone que para Claret se trata de dar con la frase que refuerce una enseñanza previa.

Cuando el tema tratado resulta algo más difícil (por ejemplo, la Trinidad), o más de índole disciplinar (como es el caso de los sacramentos), apenas aparecen referencias bíblicas. Por otra parte, incorpora a la explicación, condensadas, referencias a narraciones bíblicas que da por conocidas, y que se limita a evocar, como el caso de Sodoma y Gomorra, o José vendido por sus hermanos, o el rico Epulón. En estos casos son ejemplos de índole moral que refuerzan la explicación teórica, con la plástica de la narración sintetizada. Pero en cada una de estas ocasiones, se entiende que se trata de la narración de hechos comprobados, y ni siquiera se cuestiona su veracidad histórica. Claret participa de los mismos criterios de toda su generación, con una fidelidad literal al texto bíblico, del que se extrae una lección moral que debe ser aprovechada.

Lo anterior no se puede aplicar a otros catecismos de Claret, como el que escribió en Las Palmas en el transcurso de la misión que impartió allí: Catecismo brevísimo que solamente contiene lo que indispensablemente ha de saber todo cristiano, compuesto por D. Antonio Claret, presbítero y misionero apostólico, Las Palmas, J. B. Ortega, 1848. Éste, y 
algunos de sus otros catecismos, constituían breves síntesis en forma de preguntas y respuestas, que no daba lugar a la más mínima introducción de enseñanzas bíblicas.

Los dos más difundidos y usados catecismos del XIX, el de Santiago José García Mazo y el de Antonio María Claret no difieren de la tónica general de un escaso uso de la biblia, salvo cuando se trata de dar explicaciones. Pero incluso en este caso, la biblia es una oportunidad más de consolidar la doctrina ofrecida con el refuerzo de historias edificantes, o con enseñanzas que muestran la voluntad divina. Si cabe condensar este empleo de la biblia en una frase breve, ésta sería: la biblia está puesta al servicio de la catequesis.

\subsection{LA BIBLIA COMO ARSENAL DE EJEMPLOS}

En lo que precede, queda claro que una de las modalidades de utilizar la biblia era la de acudir a ella como recurso para dar con escenas llamativas, episodios que llamaran la atención y en los que resaltar el poder divino. Era el recurso más cómodo y sencillo, con el que parece que no se desconocía la biblia, pero con el que ésta quedaba notablemente reducida.

Una tendencia muy extendida en la catequesis desde principios del siglo XVII consistía en adobar la enseñanza teórica de dogmas, afirmaciones teológicas, o principios morales, con una serie de ejemplos. Estos, hoy serían calificados de «historietas», en el sentido menos serio y más como simple entretenimiento que la palabra historieta conlleva. Pero no sólo eran del gusto de la época, sino que además los autores de catecismos las recomendaban vivamente, al afirmar que esos hechos llamativos, extraordinarios, portentosos, eran los que llegaban a la imaginación de los lectores u oyentes, y era con lo único que se quedaban. Son numerosos los catecismos que incorporan este tipo de literatura aneja; si se eliminaran de sus páginas estas narraciones, posiblemente quedarían unos catecismos aceptables ${ }^{47}$. Pero con estos apéndices integrados en la explicación, la im-

${ }^{47}$ El proceso más llamativo lo constituyen las ediciones castellanas de la Declaración más copiosa de Roberto Bellarmino. Mientras las ediciones italianas no las incluyen, las versiones españolas están adobadas con esos relatos portentosos, que jalonan el texto como si formasen parte integrante del mismo desde su origen. 
presión que causan es la de estar en contacto no con lo divino, en el más hondo sentido, sino con lo mágico, lo inexplicable, lo que tocaba los sentimientos, pero no aportaba razones serias. A este tipo de historietas se les quería dar un tono de verosimilitud, por ejemplo, si se citaba genéricamente un autor del que se tomaba, o cuando se proponía: «Sucedió en una ciudad de Alemania...», que siempre quedaba sin comprobación.

La tendencia llegó hasta el siglo XIX, y en él, el francés Ambroise Guillois publicó Explication historique, morale et canonique du Catéchisme avec la réponse aux objectiones tirées des sciences contre la Religión ${ }^{48}$, que contenía con gran abundancia este tipo de narraciones. Pues bien, en España, Miguel Pratmans, hizo una versión de la obra francesa: El catecismo en ejemplos o la Doctrina católica esplicada (sic) con más de 650 hechos históricos, parábolas y comparaciones, Barcelona, José Gorjas, 1857. Los 650 hechos históricos que anuncia, no siempre están ajenos a la narración bíblica: aprovecha lo narrable, lo que aparece en forma de historia, tomado de las páginas de la biblia, presentado como hecho histórico indiscutible, para proponer una serie de enseñanzas conectadas con tal o cual momento de la doctrina cristiana.

No deja de ser reseñable que estas historias bíblicas aparecen entremezcladas con otras muchas historias, o historietas, a las que otorga en todos los casos idéntica validez, la misma historicidad, semejante fuerza probativa o edificante.

De esta forma, aparecen unas veces de forma literal, y otras como resumen elaborado por el autor, una serie de «historietas» bíblicas: la casta Susana (Dn 13); la historia de José y sus hermanos (Gn 37-50); Ananías, Azarías y Misael en el horno (Dn 3, 8-97); el relato condensado de la creación (Gn 1,1-26); el de la creación del hombre y la mujer (Gn 2, 7. 8-24); el de su pecado; el del ángel Rafael, compañero de Tobías (Tob 5, 4-12,20); el de san Pedro liberado de la cárcel (Hch 12,1-17),... La lista completa sería demasiado larga; y no conduciría más que a comprobar lo que ya se percibe con los ejemplos aducidos: que la biblia es vista como un arsenal de ejemplos, de historias, de narraciones llamativas o moralizantes, edificantes o asombrosas, que pueden servir para ilustrar la fe, tanto como

${ }^{48}$ Tengo noticias de la edición primera de Le Mans, 1827, y otra del mismo lugar, de 1830; hay otra edición posterior, de Lyon y París, de 1834; y otra más de Lyon, Briday, 1884. 
otras historias tomadas de escritores eclesiásticos, de fuentes de dudosa procedencia, o sin más datos para su localización y comprobación que el de proponer un título (El dogma y la moral), o un nombre (Schmith). Nada distingue los relatos bíblicos del resto; nada los resalta; nada hace ver que están dotados de otra autoridad diferente. La biblia aparece así como un copioso recurso que puede ser tenido en cuenta entre otros muchos.

El papel de la palabra de Dios ha quedado rebajado a la misma altura que la de otros relatos (que no siempre tienen visos de verosimilitud); la palabra de Dios no tiene un papel relevante o fundamental, y en ocasiones puede ser eclipsado por otra historieta que entrañe más viveza para el lector, o que excite más su imaginación. Cuando se propone la referencia que acompaña al texto bíblico empleado, nada permite ver que esto resulte más importante que el ejemplo anterior o el que sigue. Tampoco la introducción del libro destaca la importancia de la biblia sobre otras fuentes, sino que se limita a subrayar la utilidad que entraña el libro, al proporcionar al sacerdote una serie de ejemplos ya buscados, sin tener que hacer él mismo esa ingrata labor de recogida y selección.

\subsection{Dos CASOS SINGULARES}

La cerrada actitud de defensa de todo lo católico frente a otras formas de pensar llevó a algunos escritores a redactar unos «catecismos» singulares, en los que, en lugar de presentar la fe católica, se entablaba una dialéctica con otros criterios y modos de pensar. Tal es el caso de Antolín Monescillo, Catecismo católico sobre la libertad de cultos, Jaén, Saturnino Largo, 1869, y de Juan González, Catecismo sobre los fundamentos de la fe formado sobre la base del que escribió M. Aimé y considerablemente añadido, Madrid, Vda. de Burgos, 1847. Ninguno hace una exposición completa de la fe cristiana, y el uso del sustantivo «catecismo», es porque optan por el sistema de preguntas y respuestas, aunque en ocasiones resultan excesivamente largas o complejas.

Antolín Monescillo era obispo de Jaén cuando publicó su obra, de difícil lectura, compleja, y que se podría resumir como un canto de exaltación a todo lo católico, y una valoración de lo no católico como algo inconsistente y vano. Su lenguaje, rebuscado, tiene tonos de diatriba, y un marcado estilo filosófico. 
A pesar de lo cual, en alguna rara ocasión afirma con palabras de la biblia: «Dicen las Santas Escrituras que el impío habló así dentro de su corazón: no hay Dios»; o también «Qui odit fratrem suum fratricida est». Pero no hay más razones bíblicas en la parte central de su catecismo. A título de apéndices, aparecen integrados en la obra, unos capítulos de corte defensivo,-que no expositivo- con el mismo estilo beligerante de toda la obra. El capítulo $10^{\circ}$-que había publicado antes como una carta pastoralaborda incisivamente la cuestión de los hermanos de Jesús, para dejar a salvo los principios inamovibles, frente a posibles interpretaciones que resquebrajaran la fe católica; naturalmente contiene numerosas referencias bíblicas. Algunas menos aparecen en el capítulo siguiente, el $11^{\circ}$, sobre lo que el evangelio afirma acerca de la Virgen, porque no podía ser de otra forma. Lo mismo sucede con el capítulo $12^{\circ}$, sobre la idea simbólica de la Iglesia, en que acude en numerosas ocasiones a textos bíblicos para mostrar su naturaleza, fundación, actuación,... En el apéndice sobre la forma de la Iglesia y su gobierno - no se olvide que el criterio en este punto era mostrar que la Iglesia es una sociedad perfecta, frente a las que no lo son- aparecen dos textos bíblicos, que aduce con el criterio de reforzar las enseñanzas de la Iglesia. En el primer caso formula la siguiente pregunta:

«- ¿Es tan importante el estudio de las Santas Escrituras?»,

para contestar a la cual aduce el texto de 2 Tim 3,15-16, sobre la autoridad divina de la biblia, que da por sentada. En el segundo caso, la pregunta gira en torno a la interpretación de la biblia:

«- ¿Es tan claro que pertenece a la Iglesia la explicación de las Santas Escrituras?»

La respuesta la condensa en las palabras de 2Pe 1,20-21, sobre la interpretación de las profecías no por cuenta propia, sino según el Espíritu de Dios. La utilización de la biblia, interesada en función de criterios defensivos, no es precisamente la presentación de la fe cristiana a partir de lo que la palabra de Dios enseña.

En el caso de Juan González, el título de su catecismo, «sobre los fundamentos de la fe», podría inducir a un cierto error de apreciación, si se pensara que propone una explicación fundamentada de todo cuanto constituye el pensamiento cristiano. Se ciñe, al contrario, a diversos puntos, que 
son objeto de controversia, y, con el tono que corresponde a este estilo, echa mano de cinco textos bíblicos.

Cuando habla de la autoridad de la Iglesia, señala que Jesús dijo: «Id, pues, enseñad a todas las naciones...» (Mt 28.19); y cuando señala que la Iglesia dispone de autoridad de gobierno aduce el texto de Mt 18, 17: «Si tu hermano no te oye, ni a las dos personas que has tomado contigo, dilo a la Iglesia,...». La infalibilidad en la Iglesia está asegurada en Mt 28, 20, que cita: «Yo estaré con vosotros todos los días hasta la consumación de los siglos»; esa autoridad la ejercita la Iglesia por medio de una serie de ministerios, que aparecen cuando reproduce 1 Cor 12, 28ss: «Jesucristo ha dado a su Iglesia apóstoles, evangelistas, pastores y doctores para que no seamos como niños...». Finalmente, no podía faltar el pasaje que refuerza la autoridad eclesial: «El que os escucha, me escucha; el que os desprecia, me desprecia» (Lc 10,16).

Todos los textos contribuyen a la presentación de la Iglesia como una autoridad reforzada por la condición divina de su fundador, y por consiguiente, a salvo de todo fallo o error. La Iglesia, sociedad perfecta, goza de un estatuto especial del que no disfrutan sus adversarios, y por consiguiente está por encima de todos ellos.

La perspectiva de entablar polémica para contrarrestar a los adversarios de la Iglesia, en la cual se sitúan tanto Monescillo como González, les llevó a presentar respuestas a cuestiones concretas y precisas, pero no a hacer una explicación completa de la fe cristiana. Aun con esa limitación, la biblia no pasa de ser un argumento con el que silenciar a sus adversarios. Pero esta consideración está muy distante de contemplar la biblia como la expresión amorosa de Dios, que comunica a los hombres sus deseos.

\subsection{El CATECISMO ACERCA DEL PROTESTANTISMO}

Con grandes paralelismos respecto a los dos catecismos anteriores, es preciso examinar el que tenía como objetivo manifestar el rechazo visceral respecto al protestantismo. Se trata de que publicó Miguel García Cuesta, Catecismo para uso del pueblo acerca del protestantismo, Santiago, Revuelta González, 1868. Precisamente ese año, las Cortes Constituyentes aprobaron la nueva Constitución que incluía la libertad de culto, de imprenta y de enseñanza. Contra la libertad de culto reaccionó Antolín Mo- 
nescillo, como ya está anotado, e igualmente, con más agilidad, el mismo año de la aprobación de la Constitución, Miguel García Cuesta, arzobispo de Santiago.

Polarizado directamente en descalificar el protestantismo, el catecismo de Miguel García Cuesta adolece de falta de serenidad. Como no podía ser de otra forma, además de inexactitudes y descalificaciones abundantes, entra en el tema de la biblia. Muestra que la apostasía va contra la doctrina de Cristo, y lo argumenta así:

«Enseña [la Iglesia] que la Biblia o Sagrada Escritura es la palabra de Dios escrita, no por el ingenio de un hombre, como los demás libros que hay en el mundo, sino por un autor inspirado por el Espíritu Santo, que le dictaba interiormente lo que había de escribir; que los Apóstoles, enviados por el Hijo de Dios a anunciar la verdad al mundo dijeron a la Iglesia primitiva que se formaba, a los discípulos que en fuerza de sus milagros abrazaban la fe, que tales y tales libros del Antiguo Testamento eran inspirados, como lo eran también los cuatro Evangelios, las Epístolas y el Apocalipsis, que los mismos Apóstoles y sus compañeros escribieron, y estos se llaman el Nuevo Testamento; que la Iglesia primitiva o del siglo I enseñó a la del siglo II esto que le habían dicho los Apóstoles de Jesucristo; la del siglo II lo dijo a la del III, y así sucesivamente hasta hoy» (...).

Enseña que la Biblia se ha conservado íntegra y sin corrupción por la vigilancia de los pastores que siempre desecharon los libros apócrifos, esto es los libros que algunos malévolos quisieron, aun en los primeros tiempos, hacer pasar por inspirados, diciendo siempre: "No recibimos más libros como inspirados que los que nos entregaron los Apóstoles".

Enseña también la Iglesia y ha enseñado siempre que la interpretación de la Biblia no se ha dejado al capricho de cada particular, sino a aquéllos a quienes Jesucristo dijo: "Id y enseñad: Euntes docete", y éstos fueron los Apóstoles y sus sucesores los obispos con el Papa, sucesor de Pedro, a la cabeza» (p. 13-14).

Condensa en estos párrafos el criterio sostenido acerca de la biblia, de lo que se deduce un aprecio leal de la palabra de Dios, así como la función eclesial de mantenerla, transmitirla e interpretarla. Contrapone la pureza del texto frente a la inclusión de escritos apócrifos, y la interpretación eclesial frente a la libre interpretación. En estos párrafos reproducidos es moderado y calmado en su lenguaje, mientras que en otros pasajes 
no lo es tanto, especialmente cuando muestra las consecuencias de la libre interpretación, que conducen a la ruptura de la unidad.

Más adelante (p. 21-22) García Cuesta manifiesta que quien se hace protestante, abandonando el catolicismo, se rebela contra Dios, y lo hace citando el conocido pasaje del evangelio: «Si no oyere a la Iglesia (...) sea para ti como un gentil o un publicano» (Mt 18,17), así como también el otro: «Quien a vosotros oye, a mí me oye; quien a vosotros desprecia, a mí me desprecia» (Lc. 10, 16).

En este punto, García Cuesta prosigue la polémica contra los protestantes, tratando de responder a la objeción según la cual, Jesús había mandado, exigido, que sus seguidores leyeran la escritura, cosa que hacen los protestantes y no los católicos. La polémica se centra en el texto de Jn 5, 39: «estudiad las escrituras...». El argumento de García Cuesta es así:

«Nuestro Señor hablaba en este pasaje a los doctores de la ley para convencerlos, con las profecías del Antiguo Testamento, de que Él era el Mesías; y nunca intentó, como pretenden los protestantes, que la Escritura debe ser la única regla de la fe. Porque de otro modo se seguiría que sólo las Escrituras del Antiguo Testamento, de las cuales hablaba en el pasaje citado, serían la regla de la fe cristiana, lo que es una necedad.

Además, Jesucristo no dijo: "Escudriñad las Escrituras" en modo imperativo, sino "Vosotros examináis las Escrituras", esto es, vosotros acostumbráis a examinar las Escrituras. Los mismos protestantes, cuando son doctos y leales confiesan que este es el sentido obvio que se deduce del contexto, por más que la expresión sea equívoca».

De lo que antecede, Miguel García Cuesta extrae una conclusión que no deja de resultar sorprendente, y aún más equívoca que todo cuanto él mismo había dicho en las líneas precedentes. La conclusión textual es: «En suma, Jesucristo no mandó la lectura de la Biblia».

A la vista de esto, los católicos hacen bien obedeciendo a sus pastores y acatando la interpretación oficial de la biblia, pero desconociéndola, manteniendo el criterio de no leerla ni hacerla suya; y los protestantes se extralimitan en su celo porque leen apasionadamente la biblia, pero sin que exista un mandato de Jesús, y por tanto no hay necesidad ninguna de hacerlo. 
Chocante conclusión, que casi resulta contradictoria, porque García Cuesta defiende unas páginas antes que la Escritura es la palabra de Dios escrita; pero como no está mandado leerla, es cosa buena apreciar la palabra de Dios, pero para tenerla conservada en la estantería, sin leerla, porque no hay obligación alguna de consultarla. «En suma, Jesucristo no mandó la lectura de la Biblia». Es claro que de ese pasaje no se puede deducir como una exigencia cristiana la obligación de leer la biblia. Pero, como no está mandado ni exigido leerla, el pueblo cristiano, o más en particular, el católico, no la lee, y la desconoce. Es una sarcástica deducción, con la que el arzobispo de Santiago de Compostela trata de defender la postura católica, y en la que, por ironía, termina por defender la ignorancia así como el desconocimiento de la biblia. Se trataba de hacer lo contrario que lo que hacían los protestantes; no entraba en sus cálculos imitar a los protestantes -cristianos, al fin y al cabo- en lo que estaban haciendo adecuadamente en el conocimiento de la palabra de Dios.

\section{EL SIGLO XX}

Llegamos al siglo XX, en el que también hay que destacar la intervención de algunos autores que en sus respectivos catecismos dieron o no dieron cabida a la biblia en las explicaciones que ofrecieron sobre la doctrina cristiana.

Pero no hay más remedio que subdividir las actuaciones catequéticas seleccionadas en dos bloques: lo que precede y lo que sigue al Vaticano II. La diferencia es como la noche y el día, se tiene la sensación de pasar de un continente a otro, de viajar a la otra punta del mundo, porque las diferencias son tan evidentes que no hay forma de soslayarlas. Las fechas de las actuaciones de cada autor marcan, sin duda: somos hijos de nuestro tiempo y vemos las cosas tal como nos las han enseñado y como las perciben quienes están a nuestro alrededor.

Por ello, cuanto precede al Vaticano II muestra unos criterios que conectan directamente con lo que venía de siglos anteriores. Hay en verdad un tímido despegue; pero es tan tímido, tan incipiente, tan escasamente relevante, que casi ni se percibe y hay que hacer esfuerzos para no pasarlo de largo. Ahí está, sin embargo, como la constatación de un lento despertar 
del sopor de siglos. Luego será necesario pasar página, y comprobar las trazas del Vaticano II en la catequesis. Poco a poco.

\subsection{Félix Soto y Mancera}

Fue obispo de Badajoz, entre los años 1904 y 1910, cuando falleció. Era natural de Zafra, y se había trasladado a la ciudad de Cádiz, en la que había sido profesor del Seminario, además de desempeñar el cargo de doctoral en su catedral. Al cabo de unos años de episcopado en Badajoz, editó un libro titulado Lecciones de doctrina cristiana, Badajoz, 1907, prácticamente similar a un catecismo. No es muy extenso (192 páginas, en $4^{\circ}$ ) y su contenido se distribuye en 64 lecciones. Éstas, de tipo explicativo, dejan a un lado el sistema de preguntas y respuestas, para optar por una presentación de la fe por apartados numerados dentro de cada lección; unos más extensos que otros, ofrecen con relativa amplitud las explicaciones más oportunas para cada cuestión.

Las primeras cuatro lecciones versan en general sobre la religión y la revelación; no están exentas de un cierto tono apologético, y en ellas aparece claro que por la revelación, Dios se manifiesta y se da a conocer.

En el inicio mismo de la lección $5^{\mathrm{a}}$ aparece, expreso, el texto de $\mathrm{Hb}$. 1,1-2 según el cual, Dios se manifestó a través de los profetas, hasta la plenitud de la revelación en su Hijo. Esto da pie a una división de la revelación en tres etapas: $1^{\text {a }}$ etapa, la de los patriarcas antediluvianos (lección $5^{\mathrm{a}}$ ) y posdiluvianos (lección $6^{\mathrm{a}}$ ); $2^{\mathrm{a}}$ etapa, la de la ley escrita, con Moisés y la ley (lección $7^{\mathrm{a}}$ ), y los profetas (lección $8^{\mathrm{a}}$ ); y $3^{\mathrm{a}}$ etapa, la de la ley de la gracia, con Jesús, que supera y perfecciona la ley (lección 9a). La exposición condensada de todo esto da posibilidad al lector de contemplar un panorama bíblico bastante apretado, pero bastante completo.

En la p. 29, al hablar de la culminación de todo lo anterior en Jesús, resulta sorprendente esta afirmación:

«La simple lectura de los capítulos 5, 6 y 7 del Evangelio de San Mateo es suficiente para ver la perfección a la que elevó Jesucristo los preceptos de la Ley...».

Una afirmación de este tipo resultaba totalmente impensable muy pocos años antes, ya que presenta como algo normal y perfectamente realizable que los lectores de su obra tuvieran acceso sin problemas a la lec- 
tura directa del evangelio, donde podrían encontrar las enseñanzas y propuestas de Jesús. Cuando lo escribe así, parece que habría que entender que cualquier persona pudiera consultar entre sus propios libros el evangelio; la realidad, en 1907, no resultaba tan simple, pues aún se trataba de un libro de rara consulta, y de ediciones restringidas, bien en latín, en manos de clérigos, bien en castellano, pero no siempre accesibles por el coste. Sin embargo, nada de ello quita fuerza a la proposición de una consulta directa del evangelio.

De hecho, en consonancia con lo anterior, la obra de Soto y Mancera remite con frecuencia a los pasajes bíblicos que reproduce (aunque no siempre los acompañe de la cita correspondiente, que de alguna forma impide la consulta directa). Sin embargo, tales pasajes los resalta al aparecer en cursiva, destacando del resto del escrito (aunque no emplea la cursiva de forma exclusiva para los pasajes bíblicos).

Sin llegar a una abundancia notable de citas bíblicas, no se puede decir que estas resulten raras, sino que son algo habitual y perfectamente integrado en el discurrir de su pensamiento. Sin embargo, sí es posible afirmar que se está produciendo una lenta transición, en la que se nota el alborear de otro estilo. Esto hace que no se despegue totalmente de los planteamientos anteriores. Me ha parecido oportuno en este punto recoger lo que aparece en la página 34 , a propósito de la necesidad de la fe:

«La fe es necesaria para el hombre, que sin ella no puede agradar a Dios, ni llegar a la dignidad de hijos suyos (...) como enseña el Santo Concilio de Trento».

Remitir a la enseñanza de Trento es mantener la fidelidad a toda una corriente de pensamiento y de actuación; pero llama la atención que no cite antes, de forma destacada y primordial, el texto de Heb 11, 6, donde la palabra de Dios muestra esa enseñanza, que Trento se limita a repetir. Citar a Trento y no a la biblia es todo un estilo, a pesar de la apertura bíblica que el libro de Soto y Mancera muestra.

A veces, como consecuencia de una formación clerical, las citas que hace resultan un poco complicadas para quien no estuviera en la clave de un argot preciso; si a ello se añade en ocasiones la carencia de citas, resulta difícil dar con lo que quiere decir. Así aparece cuando dice: 
«El Discípulo amado lo expresó con sublime laconismo: El Verbo se hizo carne» (p. 53).

Esta muestra, y otras posibles, pone a la consideración que Soto y Mancera es deudor de toda una corriente; y que sus numerosas citas de la biblia no se despegan de un estilo de expresarse por parte de los curas, que resultaba complejo y nada sencillo para quienes carecían de formación bíblica. Si a ello se añade el dato ya apuntado de un talante defensivo bastante notable, tenemos una visión global del libro de quien fue obispo de Badajoz, que apunta nuevas formas, nuevo estilo, nuevo procedimiento de presentar la religión precisamente por la presencia de la biblia.

\subsection{Cayetano Soler}

Muy escasamente conocido, este sacerdote catalán, posiblemente de Barcelona, debía estar dedicado a la enseñanza. Publicó en $1913^{49}$ un libro titulado Tratado completo de religión, que al menos alcanzó una cuarta edición. Dispone de una no frecuente disposición, ya que tiene una primera parte sobre la apologética, que justifica por las dificultades y desprecios de que es objeto la religión; una segunda parte dogmática, que explica fundamentalmente el credo, cuyos artículos $10^{\circ}$ y $11^{\circ}$ están consagrados a los sacramentos como parte de la dogmática; y una tercera parte dedicada a la moral, de la cual, la segunda sección la constituye la liturgia.

Ya en la página 1 aparece la idea de defender la fe de las acometidas y desprecios, falsas interpretaciones y contrastes a que está siendo sometida. Todavía en el prólogo, la p. 2 incluye un párrafo que es toda una declaración de principios:

«He seguido el sistema ya empleado contra los protestantes de dar, a continuación de la verdad propuesta por la Iglesia, la sentencia bíblica, el fundamento teológico, el testimonio de la Revelación, para que se vea que los dogmas de nuestra fe no son una invención de Roma».

No he podido averiguar si el sistema a que alude, ya empleado contra los protestantes (carácter de defensa poco serena), ha sido empleado por él en alguna otra publicación, o lo ha tomado de algún autor a quien le

${ }^{49}$ Fecha del imprimatur del obispado de Barcelona: 21 de noviembre de 1913. 
hubiera dado resultado. Pero no puede por menos de subrayarse que la intención es que aparezca la frase bíblica que constituye el fundamento teológico de las afirmaciones de la fe católica; incidentalmente, también pretende que se vea con evidencia que este fundamento bíblico avala el conjunto de creencias, y que no es posible mantener que sean invención humana, romana. Por consiguiente, se puede esperar una notable presencia de la biblia, tanto en cantidad, para justificar cada afirmación, como en calidad, para mostrar los fundamentos de la fe.

Un poco más adelante concreta el sistema que ha seguido en la presentación de los datos bíblicos:

«He distribuido las citas de la Sagrada Escritura y siempre con el epígrafe Revelación, para que a simple vista se distinga lo que es fundamento inconmovible de la doctrina católica, como palabra infalible del mismo Dios» (p. 5).

Los dos párrafos anteriores parecen prometer una sólida argumentación bíblica de los contenidos de la fe. Las frases empleadas, rotundas, hacen esperar lo mejor. Y sin embargo no es así. El desarrollo de los temas está concebido con preguntas amplias a las que da respuestas también amplias y explicativas. Y solo después de haber ofrecido estas respuestas de la teología tradicional, o de otras tradiciones irrelevantes y no comprobadas (nombre de los padres de María, por ejemplo), aparece el apartado bajo el epígrafe de Revelación. Este suele consistir en un solo texto bíblico, bien referenciado, copiado íntegro, y que viene a avalar lo que ha sido presentado anteriormente. La biblia, que parecía que era el fundamento teológico de las afirmaciones de la fe, queda reducida a un aval de lo que ofrece la reflexión teológica. Los papeles se han invertido, y la biblia viene a confirmar lo ya expuesto.

Más aún: no en todas las ocasiones aparecen textos bíblicos, a pesar de que en varios momentos hubiera sido fácil acudir a alguno. Para poder vislumbrar por dónde va la intensidad de citas bíblicas, en el artículo que dedica a reflexionar sobre Dios, de 25 preguntas, sólo 11 están dotadas de algún texto bíblico; cuando habla sobre el misterio de la creación y la aparición de los ángeles, las preguntas son 26, y tan solo constan 3 textos bíblicos; al presentar la creación del mundo, figuran otros 3 pasajes bíblicos entre las 20 preguntas del tema; y al enfocar la creación del hombre, hay solo 1 proposición bíblica entre las 12 preguntas que consagra al tema. La 
proporción no siempre es igual; y en más de una ocasión, no figura ni un solo texto bíblico en un apartado concreto. Las promesas iniciales, que hacían concebir esperanzas de una adecuada utilización de la biblia, y una presencia habitual, se desinflan, y se quedan en un deseo no cumplido.

Presenta la biblia con el epígrafe de «testimonios de la revelación», y señala como equivalente los nombres de Sagrada Escritura y de Libros sagrados. Hace la descripción del antiguo y nuevo testamento y proporciona la enumeración de todos y cada uno de los libros bíblicos.

Por descontado, con todas estas limitaciones, el libro de Cayetano Soler tiene mucha más presencia de la biblia que la mayor parte de los catecismos y libros contemporáneos para la escuela. Pero produce una desilusión grande el ver que una declaración de principios como la transcrita, se queda, de hecho, en muy poca cosa. Acaso hay que reconocer que el despegue bíblico, tras años y siglos de sequía, no resultaba nada fácil; y que lo que hoy decepciona, fue en su momento un paso digno de alabanza.

\subsection{CATECismo Prescrito POR Pío $X$}

Lo habitual en España es que haya una total confusión con este catecismo. Porque, en realidad, hubo dos catecismos diversos, bajo el nombre de Pío X. En 1905 se publicó en Roma el Compendio de la doctrina cristiana prescrito por su Santidad el Papa Pío X a las diócesis de la provincia de Roma. Traducido al castellano se publicó ya desde 1906 y 1907. Dicho Compendio estaba constituido, en realidad por tres catecismos: las Primeras nociones de catecismo para niños de corta edad; el Catecismo breve. Primera parte del Compendio de la doctrina cristiana para las clases inferiores; y, finalmente, el Catecismo mayor. Segunda parte del Compendio de la doctrina cristiana para las clases superiores. La pronta traducción al castellano, además de una actitud de obediencia a lo que venía de Roma, hizo que se planteara su adopción como texto oficial en las diversas diócesis; en contra estaba el arraigo tradicional de los catecismos conocidos como de Astete, Ripalda, Ramo, Vives,... Y lo cierto es que el texto romano tuvo solo una relativa acogida, adoptado de forma oficial por las diócesis catalanas, más alguna otra y como material complementario, de consulta, en el resto de España. El mismo hecho de que integrara tres catecismos hizo que se editaran de forma independiente cada uno de ellos, y, más raramente, todo el conjunto. 
Ese catecismo venía dotado de una especie de aureola de autoridad, de forma que el papa lo prescribió en la provincia eclesiástica romana, y expresó su deseo de que fuera adoptado como texto único para toda Italia. Pronto surgieron críticas por su gran extensión, por el lenguaje empleado, por la teología de fondo que lo sustentaba, por los criterios de defensa a ultranza con visión apologética, por su visión abstracta y neoescolástica. Esto determinó que el mismo Pío X promoviera una revisión a lo largo de varios años, que dio como resultado un texto diferente y más aligerado de los defectos señalados: Catecismo de la doctrina cristiana publicado por orden de Su Santidad el Papa Pío X (Roma 1912). Sorprendentemente, este segundo texto, en el que Pío $X$ intervino personalmente, y que podría contribuir a una renovación, no fue editado en España, y se continuaron repitiendo mecánicamente ediciones del texto anterior. Se silenció su existencia, y resulta totalmente desconocido en España ${ }^{50}$.

Por consiguiente, es preciso centrarse en el primero, y dejar de lado el segundo. El Compendio, que incluía los tres catecismos, tenía un apéndice sobre las fiestas religiosas, y otro segundo apéndice titulado «Breve historia de la Religión». Este disponía de una reducida introducción, con principios bíblicos fundamentales, y a continuación dos partes, una dedicada al antiguo testamento y otra al nuevo; seguía una tercera parte, condensada, con algunas noticias de historia eclesiástica. La parte que abarcaba la biblia se desarrollaba en un total de 27 páginas, en las que desgranaba lo narrable como relato, como historia, como hechos sucedidos en que se veía la intervención divina. El apartado del antiguo testamento dedicaba una sola pregunta a los profetas, y otra a las profecías en torno al Mesías; el apartado del nuevo testamento se centraba, lógicamente en los acontecimientos relativos a Jesús, al final de los cuales aparecía únicamente la narración de Pentecostés, el apóstol Pablo y la dispersión de los apóstoles.

Con esta descripción rápida, es posible apreciar por qué sendas discurría la presentación bíblica, entendida como historia sagrada, como narración de hechos asombrosos, que proclamaban la verdad y santidad de los siervos de Dios, y el papel central de Jesús. Sin embargo, los criterios

${ }^{50}$ L. Nordera, Il catechismo di Pío X. Per una storia della catechesi in Italia (18961916) (Roma 1988). 
de interpretación bíblica estaban ausentes de unos relatos entendidos siempre de forma literal.

Hasta aquí no aparece nada de particular, respecto a otros catecismos precedentes. La exposición doctrinal estaba presentada con preguntas y respuestas en las que primaba el criterio de que todo estaba ya previsto con unas respuestas que contenían con exactitud la doctrina, y, con un marcado tono neoescolástico, buscaban la más depurada expresión, aunque resultaran abstractas, o difíciles para los destinatarios. La materia de la doctrina cristiana se distribuye en el Catecismo Mayor en cinco partes: credo, oración, mandamientos y sacramentos, más la quinta, que se centra en las virtudes, y, tras hablar de la fe y de los misterios, dedica un apartado entero a la escritura. Vale la pena transcribirlo, a pesar de resultar un poco extenso, porque esos eran los criterios «oficiales» que se respiraban en Roma respecto al mundo de la biblia y su lectura:

De la Sagrada Escritura.

P. ¿Dónde se contienen las verdades que Dios ha revelado? - R. Las verdades que Dios ha revelado se contienen en la Sagrada Escritura y en la Tradición.

P. ¿Qué es la Sagrada Escritura? - R. La Sagrada Escritura es la colección de los libros que escribieron los Profetas y Hagiógrafos, los Apóstoles y los Evangelistas por inspiración del Espíritu Santo, y que ha recibido la Iglesia como inspirados.

P. ¿En cuántas partes se divide la Sagrada Escritura? - R. La Sagrada Escritura se divide en dos partes: antiguo Testamento y nuevo Testamento. P. ¿Qué contiene el antiguo Testamento? - R. El antiguo Testamento contiene los libros inspirados escritos antes de la venida de Jesucristo.

P. ¿Qué contiene el nuevo Testamento? - R. El nuevo Testamento contiene los libros inspirados escritos después de la venida de Jesucristo.

P. ¿Con qué nombre se llama comúnmente la Sagrada Escritura? - R. La Sagrada Escritura se llama comúnmente con el nombre de Sagrada Biblia. P. ¿Qué quiere decir la palabra Biblia? - R. La palabra Biblia quiere decir la colección de los libros Santos, el libro por excelencia, el libro de los libros, el libro inspirado por Dios.

P. ¿Por qué la Sagrada Escritura se llama el libro por excelencia? - R. La Sagrada Escritura se llama el libro por excelencia, por razón de la excelencia de la materia que trata y por su Autor. 
P. ¿No puede haber error en la Sagrada Escritura? - R. En la Sagrada Escritura no puede haber error alguno, porque siendo toda inspirada, el autor de todas sus partes es el mismo Dios. Esto no quita que en las copias $\mathrm{y}$ traducciones de la misma no hayan podido deslizarse algunos yerros o de los copistas o de los traductores. Mas en las ediciones revisadas y aprobadas por la Iglesia católica no puede haber error en lo que atañe a la fe o a la moral.

P. ¿Es necesaria a todos los cristianos la lectura de la Biblia? - R. La lectura de la Biblia no es necesaria a todos los cristianos, enseñados como están por la Iglesia; pero es muy útil y a todos recomendada.

P. ¿Puede leerse cualquier traducción vulgar de la Biblia? - R. Puede leerse cualquier traducción vulgar de la Biblia, con tal que esté reconocida como fiel por la Iglesia católica y vaya acompañada de explicaciones aprobadas por la misma Iglesia.

P. ¿Por qué solo pueden leerse las traducciones de la Biblia aprobadas por la Iglesia? - R. Sólo pueden leerse las traducciones de la Biblia aprobadas por la Iglesia, porque ella sola es la guarda legítima de la Biblia.

P. ¿Por quién hemos de conocer el verdadero sentido de las Sagradas Escrituras? - R. El verdadero sentido de las Sagradas Escrituras sólo podemos conocerlo por la Iglesia, porque sólo la Iglesia no puede errar en su interpretación.

P. ¿Qué debe hacer el cristiano a quien le ofrece una Biblia un protestante o emisario de los protestantes? - R. El cristiano a quien le ofrece una biblia algún protestante o emisario de los protestantes, debe rechazarla con horror como prohibida por la Iglesia, y, si la hubiere recibido sin darse cuenta, debería inmediatamente arrojarla a las llamas o entregarla a su párroco.

P. ¿Por qué la Iglesia prohíbe las Biblias protestantes? - R. La Iglesia prohíbe las Biblias protestantes porque están alteradas y contienen errores, o porque faltándoles la aprobación y notas declarativas de los sentidos obscuros, pueden dañar a la fe. Por esto la Iglesia prohíbe hasta las traducciones de la Sagrada Escritura aprobadas antes por ella, pero reimpresas después sin las explicaciones aprobadas por la misma» (ed. 1907, p. 231-233).

Están perfectamente claros los criterios que sustentan el uso de la biblia. No es necesario acudir a la biblia, puesto que los cristianos están suficientemente enseñados por la Iglesia, y sería un esfuerzo innecesario; y, aunque afirma que es «útil y recomendada», lo cierto es que se trata de 
una mera declaración de principios, inoperantes: a lo largo de todas las páginas del catecismo no hay constancia alguna de recurrir a la biblia como algo «útil», y que, al menos sirviera para ratificar lo que la Iglesia había mostrado o enseñado; la utilidad se trastoca en inutilidad, y la teórica recomendación no aparece por parte alguna, ya que las expresiones aquilatadas del catecismo todo lo explican. Ni una sola cita bíblica.

La defensa a ultranza de la inerrancia en la biblia, particularmente en las ediciones católicas, se ciñe a las cuestiones de fe y moral, expresamente anotadas, pero se trata de blindar todo el texto dejando claro que si hay algún yerro es consecuencia de los copistas o de los traductores, pero en modo alguno hay que buscar otros responsables, pues el principio de estar a salvo del error resultaba evidente. De ahí que las versiones vulgares, suficientemente acompañadas de notas explicativas puedan ser aceptadas; pero en modo alguno se puede consentir la lectura de cuanto proceda del protestantismo, puesto que inevitablemente difundirán el error. El principio se impone con fuerza: del error no puede surgir la verdad; $y$, en consecuencia, siempre se ha de ver mala voluntad o ediciones trucadas, que han de ser desechadas.

Es posible preguntarse, a la vista del texto -y de la ausencia total de referencias bíblicas en el resto del catecismo- si esto constituía una invitación leal, abierta o animosa a la lectura de la biblia. Como expresión formal, era preciso decir lo que antecede sobre la importancia de la biblia; pero de ahí a que los cristianos la consultasen y la conociesen había una gran distancia. Estaban suficientemente enseñados por la Iglesia, y no tenían necesidad de más.

Las ediciones de los diversos catecismos de este Compendio, no alteraron lo que aparece en él. Tan sólo en otro orden de cosas, los comentarios o explicaciones que se hicieron de ellos cambiaron esto. Y lo cambiaron, como en el caso de Perardi ${ }^{51}$, con una amplia y ordinaria incorporación de textos bíblicos a las explicaciones que se les facilitaban a los catequistas, junto con ejemplos, historias edificantes, reflexiones,... que podrían servirles de ayuda. Sin embargo, esta riqueza se volvía contra sí misma, porque al tratar de ofrecer materiales al catequista para que ex-

${ }^{51}$ G. PerARdi, Manual del catequista católico (Madrid 1922). (La primera edición italiana data de 1906, a raíz de la publicación del Compendio). 
plicara las 65 páginas del Catecismo breve, se le ponían en las manos 800 páginas de comentarios, entre los cuales un apartado lo constituían los textos bíblicos, pero no era el único.

Cuando el año 1912 apareció el nuevo catecismo ordenado por Pío $\mathrm{X}$, en que intervino de forma directa, que resume en gran manera el anterior, y revisa sus contenidos, en lo referente a la biblia, tan sólo aparece una cita expresa y referenciada en la portada del catecismo, más otra en la página 89 , como conclusión de uno de los capítulos, pero de la que no se dice de dónde procede. El apéndice final, que evoca ligeramente la biblia es el que responde al título de «Cenni storici della rivelazione divina» y, en un rápido recorrido de sólo 7 páginas (112-119) esboza algunos de los principales hechos. Y la única pregunta que se refiere expresamente a la biblia (pregunta 234) dice así:

«P. Che cos'è la Sacra Srittura? - R. La Sacra Scrittura è la raccolta dei libri scritti per ispirazione di Dio nel Vecchio e nel Nuovo Testamento, e ricevuti dalla Chiesa como opera di Dio stesso».

\subsection{El CATECISMO ALEMÁN}

En octubre de 1955 se publicó el Katholischer Katechismus, obra del episcopado alemán, que había sido preparado concienzudamente en las décadas anteriores. Era un fruto esperado de la renovación kerigmática que había sido emprendida particularmente en Alemania y Austria, y que no se contentaba con una simple revisión metodológica, sino que revisaba los contenidos mismos de la fe, en orden a poner de relieve lo nuclear del cristianismo frente a tantos elementos secundarios que se entrecruzaban y que no permitían una visión clara del cristianismo. En materia de catequesis también se produjo una honda revisión de formas y de contenidos.

En 1957, a los dos años de su publicación alemana, ya se habían llevado a cabo tres ediciones en castellano (en enero, marzo y agosto), lo que denotaba que un buen número de personas estaba interesado en una nueva forma de presentar la fe. No solo se trata de un nuevo catecismo, sino sobre todo que su estilo es radicalmente nuevo. Es cronológicamente anteconciliar, pero es uno de tantos aspectos que prepararon la afloración de los criterios que después aparecieron en el aula conciliar. 
No carece de esquema vertrebrador, pero este inicia un despegue desde unos criterios puramente dogmáticos y teológicos, en los que aparecían epígrafes y afirmaciones abstractas, para dar un tímido paso a un modelo que está más cercano al destinatario del catecismo ( $1^{\mathrm{a}}$ parte: Dios y nuestra redención; $2^{a}$ parte: la Iglesia y los sacramentos; $3^{\text {a }}$ parte: la vida según los mandamientos de la ley de Dios; $4^{\mathrm{a}}$ parte: las postrimerías). Además, su estilo de redacción es profundamente antropológico, para que el lector se vea reflejado en sus páginas, en lugar de encontrar unas afirmaciones frente a las cuales no tuviera otra cosa que hacer más que obligatoriamente aprenderlas y repetirlas de memoria.

Además, es hondamente bíblico; todo él está traspasado de un sentido bíblico que se manifiesta desde principio a fin. Sea cual sea la página por la que se abra, la biblia está presente. Cada tema tiene un apartado, tras la explicación y las preguntas, que se denomina «Palabra de Dios», y que reproduce uno o varios textos del antiguo y del nuevo testamento, bien seleccionados y oportunos, así como breves; en la explicación, que constituye la parte central de cada tema, está oportuna y bien citada la palabra de Dios. El estilo de redacción adoptado, en que predominan las frases cortas, antes que los largos párrafos, permite también introducir en la explicación numerosas sentencias breves de la biblia que se insertan en la explicación de forma natural, hasta el punto de que esta aparece siempre fundamentada en lo que enseña la palabra de Dios. Ese hábil ensamblaje permite que la biblia no sea un elemento forzado que haya que insertar en una formulación teológica, sino que se constituye como la trama sobre la que se sustenta todo lo que se presenta al lector.

Cada tema viene a disponer de una media de 5 o 6 citas bíblicas, lo que permite calcular que en el conjunto de los 136 temas aparezcan por encima de las 680 citas. No aparece toda la biblia (ni se pretende siquiera), como tampoco hay una relación de relatos bíblicos al estilo de la tradicional historia sagrada. Pero la presencia de la palabra de Dios tiene una extraordinaria fuerza, al aparecer como fundamento ordinario, normal, de la fe cristiana; y esto, sobre todo, al hacerlo de forma expresa, y no sólo como algo supuesto a la vez que desconocido.

El tema 51 se puede proponer como clara referencia; se titula: «La Iglesia saca su doctrina de la Sagrada Escritura y de la tradición oral». En él describe cómo está constituida la biblia, junto con la consideración fun- 
dante de que «lo que la Iglesia enseña procede de Dios, fuente de toda verdad». Y esto que se proclama, no solo es una declaración de principios, sino el motor principal de la exposición de todos y cada uno de los temas. En lugar del criterio sustentado por el catecismo prescrito por Pío X (el de 1905), según el cual «la lectura de la Biblia no es necesaria a todos los cristianos, enseñados como están por la Iglesia», el catecismo alemán opta por el criterio de que los cristianos sean enseñados por la Iglesia con la propia palabra de Dios como fundamento. Se han invertido los términos. La distancia entre ambos criterios resulta abismal.

Con este catecismo se ha producido un punto de inflexión respecto de los siglos precedentes, en que la palabra de Dios estaba ausente del horizonte catequético de los cristianos. Con él están brotando los primeros y tempranos frutos conciliares.

\subsection{El CATECISMo de la DOCTRINA CRISTIANA. TEXTo NaCional}

A diferencia del catecismo anterior, el texto nacional surgido en España es buena muestra de que junto a los avances, también existen los frenazos.

Aparecido su Primer grado el año 1957, tras una lenta gestación, pretendía hacer frente al problema de la multiplicidad de textos tradicionales en las diócesis españolas, algunos de los cuales tenían a sus espaldas siglos de implantación y uso. Pero al producirse el cambio, no se aprovechó la oportunidad de sustituirlo por uno mejor, porque la mentalidad, los criterios, la formación de los responsables de la Iglesia española en aquellos años de posguerra y de aislamiento marcaban otros derroteros. El apego a unas formas tradicionales y convencionales pesaba demasiado.

Se publicó este primer grado en 1957; es el mismo año en que se publicaron tres ediciones castellanas del Catecismo católico, ya examinado. Pues bien, el balance de su examen es demoledor: este catecismo no tiene ni una sola cita de la palabra de Dios.

Hay que echar la vista al Segundo grado, publicado en 1958. El silencio absoluto del catecismo de Primer grado en torno a la palabra de Dios se rompe, aunque muy tímidamente. Aparecen tres citas bíblicas. La primera con un dibujo de Jesús que enseña a sus discípulos a rezar, y el texto de Mt 6, 8-9 (p. 2). La segunda, a continuación de los mandamientos, con la incorporación de «el mandato nuevo de Jesús» y el texto de Jn 13, 34- 
35 (p. 8). La tercera, al final del impreso, con un dibujo que representa a Jesús como sembrador, junto con el texto de la parábola de Lc 8,11-15 (p. 70). No hay más. La verdad es que tres citas bíblicas son realmente poco.

Cuando en la p. 11 se incluye una pregunta que pretende concitar al asentimiento de los niños a los que se destina, se formula de esta manera:

«¿Qué es el Catecismo? - El Catecismo es el resumen de la doctrina enseñada por Jesucristo, que todo cristiano debe saber y practicar».

Pero esa doctrina enseñada por Jesucristo, resumida y acomodada, no aparece de forma intuitiva, a los ojos de los niños, como algo que descubrimos en las páginas bíblicas, donde encontramos sus palabras, su mensaje, su estilo de vida. Es una declaración de principios inoperante, porque el niño no percibe que lo que se le enseña y lo que contiene el catecismo haya sido enseñado por Jesús, aunque se le diga que es así. Tres únicas citas, y la presentación de una doctrina que se dice que viene de Jesús, aunque no se vea.

En el propio texto hay, además, una magnífica oportunidad, desperdiciada. Porque contiene numerosos dibujos, algunos de los cuales hacen referencia directa a pasajes bíblicos, pero a los autores del libro les pareció que el dibujo era suficiente, y que no había necesidad de más. De ahí que la evocación plástica quedara inoperante, muda, al no estar acompañada por la escena que trata de presentar ${ }^{52}$. Hacer la lectura bíblica correspondiente podría quedar a criterio del catequista, aunque no siempre es seguro que esto se llevara a cabo. Las sucesivas evocaciones podían quedar como simples complementos, igual que otros dibujos que no tienen una resonancia bíblica. La fuerte dependencia en España de una tradición multisecular de prescindir de la biblia en la catequesis pasaba factura. En contraste con lo que se publicó en Alemania (y se difundió en las ediciones castellanas) por las mismas fechas conviven dos concepciones bien diversas, sin apenas punto de contacto.

${ }^{52}$ Las escenas dibujadas son estas: P. 13: bautismo de Jesús; p. 15: la creación; p. 18: el pecado original; p. 21: el descendimiento y la resurrección; p. 23: Pentecostés; p. 25: la vid y los sarmientos; p. 26: el perdón de los pecados; p. 28: Cristo como juez; p. 31: la negación de Pedro; p. 37: Jesús ante Pilato; p. 39: la entrega de las llaves a Pedro; p. 44: el centurión ante Jesús; p. 47: el discurso de Pedro en Pentecostés; p. 50: el fariseo y el publicano; p. 51: la conversión de Pablo. 


\subsection{El ignorado Proyecto definitivo}

Al hablar del Catecismo de la doctrina cristiana. Texto Nacional, no hay más remedio que echar la vista a lo publicado. Sin embargo, resulta obligado romper el orden lógico, para volver a los esquemas preparato$\operatorname{rios}^{53}$. Entre los borradores impresos enviados para hacer indicaciones y mejoras, es preciso destacar el último de ellos, que responde al título de Catecismo de la doctrina cristiana. Texto único nacional. Proyecto definitivo, Valencia, Semana Gráfica, 1956. En el mismo, una advertencia previa fija la atención en los distintos cuerpos de letra, que responden a los cuatro grados en que se había previsto el proyecto. El cuarto grado era el que aparecía impreso «en letra de menor tamaño y sin preguntas», es decir, meramente explicativo.

Este cuarto grado no se llevó nunca a la práctica, y cuando se editó, en 1962, el denominado «tercer grado», se fundieron en él tanto las preguntas previstas para el nivel superior (o tercer grado), como las explicaciones que se reservaban para el cuarto grado. El hecho de que este pequeño libro haya sido utilizado solo para consulta, en tanto se llegaba a los textos oficiales hace que su acceso sea muy difícil.

${ }^{53}$ En L. Resines, La catequesis en España, 792-801; en p 797: «Por ello, inmediatamente antes de la fecha de aparición, se completa el ciclo de consultas con otro folleto de la Comisión Episcopal de Enseñanza, Catecismo de la doctrina cristiana. Texto único nacional. Proyecto definitivo, Valencia, Semana Gráfica, 1956. Este folleto recogía lo que había sido publicado en los anteriores, lo ampliaba ligeramente en cuanto al número de respuestas, pero introducía una notable variación: con bastante frecuencia a medida que parecía oportuno, intercalaba con otro tipo de letra breves explicaciones entre pregunta y pregunta; tales explicaciones, abundantes, incorporaban en ciertas ocasiones textos bíblicos, ejemplos, reflexiones, o ampliaciones a los conceptos más difíciles, haciendo posible una intelección de lo que estaba enunciado en la pregunta que iba acompañada de una explicación. La novedad no puede dejar de constatarse, ni es justo pasar por ella con tal rapidez que no se la valore adecuadamente, pues el hecho de romper el molde del pasado, de simples preguntas y respuestas, para pasar a otro esquema distinto, ha de ser tenido como un paso valiente. No se trata de las grandes y extensas explicaciones de los catecismos para adultos, sino de párrafos en general bien pensados (algunos con un estilo teológico subido), que buscaban el acompañamiento del catequizando, a la vez que suministraban al catequista o al maestro, fundamento suficiente para hacer una exposición válida. Sin embargo, esta notable aportación no pasó a los textos definitivamente aprobados, que fueron publicados sin ella». 
Pero para el empeño de este trabajo, resulta de una consulta poco menos que imprescindible, por lo que supone de comienzos de un giro en materia de incorporación de la biblia. Después de haber visto lo de los grados primero y segundo, nada había que añadir respecto a las preguntas que se reservan para el tercero, en un orden cíclico, que para entonces era una adquisición ya normal.

En cambio, cuando se pone la vista en el cuarto grado, con explicaciones pero sin preguntas, sorprende que este proyecto abra las puertas sin problema a la incorporación masiva de textos bíblicos, casi como un torrente, en auténtico aluvión respecto a la carencia total que apareció cuando se publicaron en 1957 y 1958 los textos oficiales de primer y segundo grado.

En este Proyecto definitivo, siempre en lo relativo al cuarto grado, en letra de cuerpo menor, para explicación y complemento, aparecen nada menos que 97 pasajes bíblicos. Una irrupción insospechada, que nada hasta entonces hacía prever. Los textos están ordinariamente fundidos con breves explicaciones, impresos en el mismo tipo de letra, sin más elementos que los destaquen que las comillas, más las citas correspondientes (en alguna rara ocasión se omite la cita). Los textos están bien seleccionados, con oportunidad respecto al tema que se trata en cada momento. De los posibles textos para cada tema, suelen estar presentes las más notables enseñanzas bíblicas, aunque en ciertas ocasiones cabe pensar en la mayor o menor oportunidad de algunas frases.

En algunas ocasiones no se ofrece el texto bíblico propiamente dicho, sino una síntesis, que no es literal, aunque recoge el sentir bíblico. Así, una síntesis de Rom 9, un tanto forzada, sobre la voluntad divina de poner a Adán como cabeza del género humano. Otra síntesis, igualmente forzada, es la que remite a Gal 5, 22-23, con arreglo a la cual propone los consabidos doce frutos del Espíritu Santo, que en el texto bíblico no aparecen asi ${ }^{54}$. Hay además otra síntesis que trata de condensar los principales momentos de la vida de Jesús, en apretado compendio bien realizado. En cambio, resulta curioso que se propongan las bienaventuranzas como si se tratara de un formulario ordinario de la catequesis, y no se haga constar

${ }^{54}$ Gal 5, 22-23: «En cambio el fruto del Espíritu es amor, alegría, paz, paciencia, afabilidad, bondad, fidelidad, mansedumbre, dominio de sí». 
que es una enseñanza bíblica que procede de Jesús, ni se den pistas para su localización.

No vale la pena hacer una larga relación de las 97 ocasiones en que está citada la biblia, para juzgar la oportunidad o el acierto de cada cita seleccionada. Sería una lista larga en exceso. Pero sí que es imprescindible hacer otra consideración. Para ello es obligado tener presente que el proyecto se había concebido como un catecismo cíclico, que en su grado cuarto, el último, incorporaba tales textos bíblicos. Por eso, tal como figuran en la disposición tipográfica, aparecen en cada tema, dosificadas, las preguntas de los grados primero, segundo y tercero, y, siempre a continuación, la explicación del grado cuarto. Sería imposible analizar todos los casos, pero sirve un ejemplo para caer en la cuenta de lo que presenta: en el tema de la gracia (p.127-128) aparecen preguntas sobre la gracia como medio principal para la santificación (grado tercero), qué es gracia (grado primero), cómo puede ser la gracia (grado segundo), qué es gracia actual (grado segundo), y a continuación la explicación para el grado cuarto que dice así:

«Dios concede a todos los hombres las gracias necesarias para salvarse. Si alguno se condena es por su culpa, por haber resistido a estas gracias. “...El cual quiere que todos los hombres sean salvos" $(1$ Tim. 2, 4)».

Es claro que se ha producido una inversión de términos respecto a lo que hoy se entiende debería ser el uso de la biblia en la catequesis. En el proyecto definitivo, el texto bíblico aparece al final, reservado para el cuarto grado, como remate y complemento de una enseñanza que ha seguido los pasos siguientes:

- primer grado: qué es gracia;

- segundo grado: cómo puede ser la gracia; qué es gracia actual;

- tercer grado: cuál es el principal medio para la santificación;

- cuarto grado: Dios concede sus gracias; el hombre puede resistirse; pero Dios quiere la salvación para todos.

La reflexión teológica, doctrinal; la elaboración de subdivisiones en la gracia, son nociones que se considera que ha de saber el cristiano; y tan solo cuando se llega al nivel superior aparece la consoladora enseñanza de que Dios quiere que todos los hombres se salven. En lugar de ser este 
el punto de partida, la fuente de la que dimana, el primer puesto lo ocupa la reflexión de los teólogos, la conveniencia o subdivisiones, las explicaciones humanas. Si el texto bíblico tuviera la consideración fontal, aparecía en primer plano, pues no resulta nada difícil de comprender incluso para los niños pequeños; y desde ahí tienen sentido las definiciones, aplicaciones, o divisiones que no tendrían que empañar la pujanza de la palabra de Dios.

Pero eran otros tiempos. Y bastante era con que hiciera su aparición la escritura en el panorama de la catequesis, aun con todas las cortapisas: que estuviera reservada para el cuarto grado, que estuviera en letra que no se diferenciaba de otras explicaciones, que no llegara a todos. Por eso, no hay más remedio que realzar este desconocido Proyecto definitivo, y saludar que en él desembarcara la biblia en la catequesis de una manera articulada, ordenada y realmente nueva en el panorama español.

\subsection{EL TEXTO NACIONAL. TERCER GRADO}

Por fin, en 1962, fue publicado el tercer grado del catecismo. El grado primero, lo fue en 1957 y el grado segundo en 1958. Pasaron cuatro años hasta que el tercero vio la luz. En él se vieron hechas realidad algunas de las propuestas que aparecían en el «Proyecto definitivo», a que me he referido antes. Se rompían moldes, pero con una particularidad: aunque en ninguna parte se mencione, lo que estaba detrás, como referencia y modelo a imitar, era el catecismo alemán (Katholischer Katechismus), en cuanto a la forma y a la disposición, pero no así en cuanto al contenido, y la orientación de fondo.

«Lo cierto es que este Catecismo de la Doctrina Cristiana. Grado Tercero heredaba algo, poco, del prácticamente olvidado «Proyecto Definitivo», de 1956, que contenía algunas explicaciones junto a las preguntas y respuestas. Y en su mayor parte, era un calco, malo, deficiente, del Catecismo católico, traducido del alemán. Se había limitado a copiar el formato externo del texto alemán, pero en lo relativo a la teología de fondo, así como en la concepción de la obra la diferencia era abismal. (...) Cuando en 1962 aparece el Catecismo de la Doctrina Cristiana. Grado Tercero, el catecismo alemán iba ya por la $11^{a}$ edición castellana: de ninguna manera era un texto ignoto o que hubiera pasado desapercibido, sino todo lo contrario. El hecho de que se tradujera a 30 lenguas es buena prueba de su ca- 
lidad intrínseca, ampliamente reconocida. Y sin embargo, al texto español que aparecía en 1962, ya en vísperas del Concilio, solo le llegaba el esquema externo de las lecciones: una exposición amplia, a la que seguían las preguntas (ordinariamente muchas y densas, frente a las pocas y bien pensadas del texto alemán), una referencia a la liturgia (algunas veces traída por los pelos), a la oración, y un texto breve para ser recordado. El aspecto bíblico, estaba entremezclado en la explicación primera y, en ocasiones, en la frase final para el recuerdo» ${ }^{55}$.

Es el momento de pararnos a contemplar la presencia de la biblia en este catecismo. Cada tema (denominado «lección», con evidente resonancia escolar) comienza por una introducción que podría denominarse «explicación», aunque carezca de epígrafe propio, en letra de cuerpo pequeño; sigue la parte de preguntas y respuestas, abundantes, y concluye con tres referencias a la liturgia, la oración personal, y una frase para encomendar a la memoria; todo esto que sigue a la «explicación» figura en letra de cuerpo mayor. En las «explicaciones» se entreveran con abundancia las referencias bíblicas, unas veces breves y otras más extensas. Esto también se había hecho en el catecismo alemán, y suponía la ventaja de que la fundamentación bíblica no aparecía como algo aislado, sino vinculado a la reflexión que toda la «explicación» ofrecía. Las referencias bíblicas son completas, reproduciendo el texto entrecomillado y bien citado. Y varían en número, dependiendo del tema tratado. Se podría hacer una media de unas seis citas bíblicas en la «explicación» de cada tema, lo que quiere decir que en los 55 temas hay aproximadamente un total de 330 citas. No es un número despreciable.

Las citas están bien seleccionadas, con oportunidad, y bien relacionadas con cada tema; hay variedad, aunque abundan, como es natural, las del nuevo testamento respecto a las del antiguo. Si hay que decir en verdad que en la «explicación» las razones que se ofrecen están bien trabadas con los textos bíblicos, con la misma verdad hay que reconocer que toda esa información bíblica apenas tiene repercusión inmediatamente después en las preguntas y respuestas. Estas aparecen informadas de una teología dependiente de los criterios tradicionales de la catequesis y de la teología que se practicaba en España. En la misma condición hay que situar el es-

${ }^{55}$ L. Resines, La catequesis en España, 799. 
quema al que responde el catecismo, concebido como una serie de propuestas que deben ser aprendidas, para, una vez sabidas, ser buen cristiano. De ahí que predomine el elemento informativo, de conocimientos, de «saberes» que han de ser aprendidos con la misma exactitud con que han sido expresados en el catecismo. Planteado así, la riqueza bíblica, así como la que se puede encontrar en las «explicaciones» con que se inicia cada tema, quedan en gran forma inutilizadas.

No hay más remedio, pues, que reconocer que este catecismo no estaba transido de un sentido bíblico en lo que transmitía. Esta serie de conocimientos estaba vinculada a los criterios escolásticos tradicionales, anclados en la preocupación por la integridad y por la ortodoxia, aunque digan poco al destinatario. La biblia aparece como un elemento introductorio, no despreciable; pero en modo alguno nuclear.

Lo dicho tiene una doble comprobación. Por un lado, en la p. 26, en el tema inicial sobre el credo, se habla de la revelación divina (escritura y tradición); y se explica con amplitud lo relativo a la escritura. Llega un momento de la «explicación» en que aparece esto:

«No todos están obligados a leer la Sagrada Escritura, porque ya la Iglesia nos enseña las principales verdades que contiene; y, por otra parte, por ser libros tan antiguos y difíciles de entender, no todos podrían sacar fruto de su lectura.

Sin embargo, la Iglesia nos aconseja y desea que la leamos, con tal que sea en ediciones por ella aprobadas, que siempre tienen notas aclaratorias de los puntos más difíciles.

Debemos estar en guardia y rechazar las ediciones de la Biblia hechas por autores no católicos, que a veces omiten varios libros sagrados, o alteran el texto, y carecen de las debidas notas aclaratorias».

Es más que notorio que están resonando las palabras - ya citadasque aparecían en el catecismo publicado en Roma en 1905, y que había sido prescrito por Pío X para la provincia eclesiástica romana. Los criterios de 1905 marcaban la mentalidad de quienes aprobaban y avalaban el catecismo que se publicaba en 1962, a las puertas mismas del concilio.

La otra razón es estrictamente posconciliar. Los criterios que fueron cristalizando en los documentos conciliares dejaban desfasados muchos de los razonamientos y fundamentos que aparecían en las explicaciones 
con que se abría cada tema. Ante este hecho, mientras surgieron otros catecismos con estilo netamente diferente, este fue mantenido casi en plan numantino por el episcopado, argumentando que era el texto oficial que había sido aprobado por el episcopado.

Y entonces, en 1971, nueve años después, se procedió a una edición cercenada respecto a la anterior, que únicamente contenía las preguntas y respuestas, y que en cubierta y en portada hacía constar: «Formulario oficial de preguntas y respuestas extraído del Texto Nacional». Se producía, pues, en pleno posconcilio, la inconsecuencia de que sólo se mantenían las preguntas y respuestas, que eran lo fundamental del catecismo nacional en su grado tercero; mientras que las explicaciones previas, donde estaban presentes con abundancia y oportunidad las enseñanzas bíblicas quedaban eliminadas. Durante varios años se mantuvo esta edición, y, con ella, la inconsecuencia, hasta que en 1976, tras catorce años, se publicó el titulado Con vosotros está, que lo sustituía.

\subsection{El Nuevo Catecismo para adultos (CATECismo holandés)}

En 1966, a la clausura misma del concilio, vio la luz el que fue conocido por su origen como «Catecismo holandés», si bien su verdadero título propone otros matices no despreciables: Nuevo catecismo para adultos. Y lo era en verdad. Era nuevo en su concepción, en su planteamiento, en su estilo de proponer afirmaciones, en asumir preguntas e interrogantes del ser humano, en su mano tendida a los creyentes de otras religiones. Y era para adultos, ya que así lo indica la presentación de la fe cristiana a lo largo de 500 páginas, como finalidad perseguida por el Instituto Catequético de Nimega.

Pero, además, era el fruto primero del concilio. No se trataba en modo alguno de un fruto inmaduro, precipitado, sino todo lo contrario: había sido elaborado por medio de una amplia consulta sin reservas a cuantos pudieran aportar en Holanda algún punto de vista que resultara válido para expresar uno u otro punto de la fe. Toda esa amplia serie de aportaciones enriquecieron un esquema que el Instituto Catequético había trazado, y que tenía muy presentes los criterios que habían aparecido en el aula conciliar. En cierto modo hay que decir que se trataba de los mismos criterios, sin esperar a que los documentos conciliares fueran votados y aprobados oficialmente, ya que algunos de sus portavoces estaban tam- 
bién colaborando en la redacción de este catecismo. Un trabajo serio, de varios años de duración, con la vista puesta en la redacción de un texto que pudiera ser leído con facilidad, soltura y aprecio por parte de los adultos creyentes; estos disponían así de un texto acomodado a los planteamientos del hombre de nuestros días, con interrogantes sobre su fe, en convivencia diaria con cristianos de otras confesiones cristianas así como con creyentes no cristianos.

El resultado pretendido fue enseguida apreciado por sus destinatarios naturales, y, precisamente por la novedad que suponía su estilo franco y dialogante, pronto se difundió merced a las traducciones a varias lenguas. Era una bocanada de aire fresco, que proponía la fe cristiana con seriedad, sin tener que echar mano de un lenguaje de corte dogmático, abstracto y difícil. Y por esto pronto se ganó el aprecio de los lectores. Bien es verdad que los grupos más refractarios a la apertura conciliar de miras encontraron una serie de inexactitudes, de afirmaciones no matizadas, o de nuevas expresiones que parecían poco adecuadas para aquilatar con justeza la enseñanza tradicional. Las quejas suscitaron una reacción que obligó - tras varios años y numerosas reflexiones - a publicar un suplemento que sustituía algunos pasajes por otros más ajustados a la doctrina tradicional, igualmente dotados de un lenguaje más tradicional, con el que se pretendió poner punto final a las encendidas posturas a favor o en contra del catecismo.

Pero en lo que respecta a la utilización de la biblia, no hay más remedio que decir que se trata de un uso ejemplar. La enseñanza bíblica está presente a lo largo de todo el escrito. Es verdad que hay páginas en que no se cita ni una sola vez (por el tema que aborda, por ejemplo); pero a lo largo de su desarrollo hay una permanente consideración de la palabra de Dios como fuente de la que se surte el cristiano y la comunidad para fundamentar y expresar su fe. Incluso en algunos pasajes en que no se cita de forma expresa, pero se está haciendo una proposición de enseñanzas dogmáticas o morales, el trasfondo bíblico que sustenta las afirmaciones es claro. Además, las referencias en el texto son abundantes y oportunas; y las citas literales, a las que se recurre con asiduidad, constituyen el entramado sobre el que se construye la presentación de la fe.

Al finalizar la parte segunda, tras haber hablado de la experiencia religiosa del pueblo de Israel, a través del cual Dios se ha manifestado a la 
humanidad, dedica 20 páginas (p. 47-67) a la explicación de los aspectos más notables de la palabra, oral y escrita, que reviste la forma de escritura en la que Dios se hace presente en la experiencia religiosa de un pueblo, Israel. Esto cristaliza en una buena presentación del antiguo testamento, y los criterios básicos para su lectura.

Más adelante, en la parte cuarta, tras haber presentado la figura de Jesús, hace algo similar al presentar cómo la experiencia vivida por los testigos presenciales empieza a tomar forma en escritos que centran el descubrimiento de que Dios se ha manifestado en su Hijo, Jesús; en él han percibido la culminación de la revelación de Dios, y los escritos del nuevo testamento reflejan y transmiten esa experiencia, bajo la inspiración del Espíritu.

Nada forzado en el empleo de la biblia. Discurre con la misma naturalidad con la que se acude a una poesía, o a una reflexión, o cuando se propone un ejemplo o anécdota. Acaso este sea el mayor valor: al resultar tan natural su empleo, parece que discurre por la vía de lo que se espera como lógico, sin que llame la atención más que cuando se trata de algunos textos poco usuales.

En una expresión sincera de verdad religiosa, y de sabia humildad, los autores del catecismo tienen la elegancia de saberse retirar a un lado para dejar paso, por derecho propio, a la palabra misma de Dios. Aparece expresado así:

«Tal vez convenga decir aquí algo sobreentendido más de una vez en el curso de este libro, a saber: este catecismo tiene por objeto exponer claramente la doctrina viva de la fe; pero en la Sagrada Escritura se encontrará siempre más vida, más calor, fuerza y verdad. Cuando uno lee directamente la Sagrada Escritura, nos viene como una llama que nos inflama, un calor de fe, de experiencia viva, de revelación divina. Es el ardor de las palabras mismas de Jesús. La biblia no separa ni analiza las cosas, sino que, por lo general, las trae juntas, lo mismo que en la vida las cosas están juntas, implicadas» (p. 457).

Lo cierto es que esto no se quiere dar por sobreentendido, y dejar correr las cosas, para que haya quien lo descubra, en tanto que otros no lleguen a hacerlo. El propio catecismo cede la prioridad a la palabra de Dios, que en modo alguno intenta sustituir ni suplantar. En todo caso, la función mediadora del catecismo, para explicitar algunas afirmaciones, o 
sistematizadora, para presentarlas con un esquema ordenado, no deja de tener una importancia siempre secundaria respecto a la que se reconoce a la palabra de Dios. ¡Cuánta diferencia en comparación con otros textos de catecismos que no la citaban siquiera, o que la solapaban entre explicaciones! Palabras modélicas, que resultan nuevas, cuando en realidad, las cosas deberían haber discurrido siempre en otra dirección; de ser así, no hubiera sido preciso escribir el párrafo anterior.

\subsection{CON VOSOTROS ESTÁ}

El primer fruto de la catequesis del posconcilio en España fueron los denominados Catecismos escolares que fueron publicados con la intención de suministrar una referencia válida a la enseñanza religiosa que se desarrollaba en las escuelas. Por consiguiente, aparecieron graduados conforme a los cursos de la que se denominaba Educación General Básica, de tal forma que a cada curso correspondía un catecismo. Con ello se conseguía un doble objetivo: graduar la materia que debía ser enseñada en cada curso, de forma que hubiera una progresión de uno a otro; y además, que se llevara a cabo una síntesis a la conclusión de cada uno de los dos ciclos, que sirviera para sistematizar y estructurar armónicamente lo aprendido.

Como fruto derivado del concilio, donde se había puesto de relieve la importancia que tenía para los cristianos la palabra de Dios, esta se hacía presente de forma natural y progresiva, a medida que los cursos progresaban, y aparecía claro, a los ojos del niño que manejaba cada uno de estos catecismos, que la palabra de Dios no era un apéndice, sino un elemento que había que tener en cuenta en el aprendizaje de la religión; y, poco a poco, que este era un elemento central.

Esta presencia de la biblia puso de manifiesto que muchos maestros no estaban muy duchos en el manejo y conocimiento de la misma, y hubo que organizar, en consecuencia, unos mecanismos que hicieran posible un conocimiento básico, que dejara atrás los planteamientos anecdóticos de lo que hasta entonces había sido la historia sagrada.

Cuando se publicó en 1976 el catecismo titulado Con vosotros está, habían transcurrido diez años desde la finalización del concilio, y había ya una experiencia de diez años en el empleo habitual de la biblia en la escuela. De ahí que este nuevo libro enriquecía y ampliaba lo que ya estaba presente en los que se habían publicado antes. 
Con esta obra se trataba de responder a la enseñanza religiosa de los preadolescentes, en los últimos cursos $\left(6^{\circ}, 7^{\circ}\right.$ y $8^{\circ}$, que correspondían a los 11,12 y 13 años), con los que concluía la escuela primaria. Estaba previsto que el mismo libro sirviera durante el desarrollo de los tres cursos, y se confiaba que los maestros fueran quienes seleccionaran los temas correspondientes a uno u otro curso, según estimaran oportuno. La dificultad en la presentación era que el libro se había editado en cuatro tomos, por lo cual, muchos educadores simplificaron el asunto utilizando un tomo para cada curso, y dejando uno sin consultar. Por otro lado las más de 600 páginas de la obra hacían que, en una distribución equitativa, correspondieran unas 200 para cada curso, lo que se demostró ineficaz, ya que muchos temas precisaban un desarrollo pausado.

A pesar de que esos eran los destinatarios naturales para los que se había diseñado el catecismo, no deja de ser cierto el aserto de algún responsable conocedor del tema que afirmó que firmaría sin problema que los padres de los niños conocieran el contenido de la fe allí presentado. El catecismo para preadolescentes se mostraba más útil para los padres que para sus hijos.

Ahora bien, las cualidades positivas del texto le acercaban mucho a la sensibilidad y modo de percibir las cosas por parte de los muchachos. Era un catecismo que partía de la experiencia humana, entremezclada con las propuestas de reflexión, de enseñanza doctrinal o moral, de tal modo que no había una escisión en compartimentos para desarrollar cada tema, sino un discurrir fluido, en el que se hacían presentes sin violencia ni estridencia todos los elementos que lo integraban.

Entre ellos, con una importancia notable, aparecía la biblia. Es cierto que no hay un tema que específicamente se ocupe de enseñar o mostrar qué es la biblia, puesto que resultaba algo que era manejado de modo ordinario, tanto en el propio catecismo, como en los de los cursos anteriores. La palabra de Dios se entremezclaba con las palabras y reflexiones humanas, para presentar de esta forma el cristianismo, inserto en la vida, las preocupaciones, las alegrías y los deseos del destinatario. Esa forma de insertarse la biblia, llena de ventajas, evitaba todo cuanto pudiera sonar a un elemento que se incrustara a la fuerza. Por otro lado, se había elegido un estilo literario en que predominaban las frases cortas frente a los períodos largos; esto hizo que la palabra de Dios fuera presentada con ese 
mismo estilo, y ello hacía posible una gran abundancia de textos que jalonaban la enseñanza.

El tema que podría aproximarse un poco más a lo que podría entenderse como una presentación de la biblia era el tema $8^{\circ}$, que responde al título de «Los profetas. Nos encontramos con Cristo en los que anuncian su palabra. En ellos quiere ser escuchado». En las 6 páginas dedicadas al tema aparecen 20 textos bíblicos: la mayor parte de ellos transcritos, y algunos sólo como referencias. Además, ordinariamente la palabra de Dios es citada resaltándola por medio de un recuadro que enmarca cada cita; en otras ocasiones, -inscrito en el desarrollo del texto- aparece entrecomillada, o solo la referencia. Así presentada, la palabra de Dios tiene una evidente relevancia que no hace falta resaltar especialmente, porque se deduce desde el manejo ordinario del libro.

Esta apreciación cualitativa a la hora de acudir a la biblia se complementa con una apreciación cuantitativa. No resulta tarea sencilla enumerar todas y cada una de las ocasiones en que la biblia es citada. Pero haciendo una estimación media seleccionando varios temas, se puede concluir que la biblia aparece unas 11 veces aproximadamente en cada uno. Puesto que son 74 los temas presentados, la biblia está presente en no menos de 800 ocasiones en este catecismo.

Tanto la cantidad, como el que aparezca como un recurso frecuente, habitual, normal, hace que a los ojos del muchacho, la biblia se integre también de forma habitual y normal en su formación como cristiano. La presencia del antiguo testamento es, por lógica, menor que la del nuevo; pero de ninguna manera se puede decir que esté ausente de sus páginas.

No es posible dejar de hacer una comparación con otros textos anteriores al Vaticano II, incluso de tiempos no excesivamente lejanos. Frente a la presencia de los profetas, como un episodio más de la historia sagrada, en cierto modo marginal, y no siempre tratado, los profetas aparecen como los portavoces de la palabra de Dios para su época, con las exigencias de un culto purificado, de una justicia social inaplazable, de la defensa de los débiles y marginados de la sociedad, con la fuerza de denunciar los abusos en el ejercicio del poder, o en el comercio, o señalando los abusos de las clases dirigentes. Se hace una muy válida síntesis de los más destacados aspectos de su misión, como centinelas del pueblo de Israel; y se invita a los cristianos a sentirse profetas en el nuevo pueblo de Dios, manifestando con la palabra y con el testimonio su condición de pueblo profético. 
La diferencia con esos textos anteriores supera, con abundancia y recto sentir, la sequía que hasta entonces habían sufrido los catecismos respecto a la presencia de la biblia. Parecían olvidados aquellos textos de catecismo que jamás citaban la biblia, y en los que aparecía la reflexión elaborada por la teología, pero distante de sus fuentes. Entre uno y otro estilo, había tenido lugar la celebración del concilio Vaticano II. Era normal que surgiera otro estilo bien diferente, de acuerdo con sus enseñanzas:

«El Concilio recomienda insistentemente a todos los fieles (...) la lectura asidua de la Escritura para que adquieran la ciencia suprema de Jesucristo, 'pues desconocer la Escritura es desconocer a Cristo'» (Dei Verbum, 25).

\subsection{Rudolf Becker, Marie Luise Fischer, Gottard Fuchs}

Estos tres autores alemanes resultan poco conocidos en España, a pesar de que la traducción de su obra conjunta ha conocido varias ediciones. Aunque la suerte editorial, o la fama de los que han escrito catecismos, no siempre vayan parejas. La obra que han redactado se titula Exposición de la fe cristiana. Catecismo católico para el estudio personal y la ense$\tilde{n} a n z a^{56}$. El título es absolutamente exacto, puesto que se trata, en verdad, de una exposición bien elaborada y equilibrada de la fe cristiana. El empleo del adjetivo «cristiana» podría hacer suponer a más de uno que se trata de una presentación de cualquier confesión cristiana, evangélica o luterana, por ejemplo. Pero el subtítulo despeja inmediatamente todas las dudas, cuando asegura que se trata de un catecismo católico.

Desconozco si en la edición alemana hay alguna advertencia sobre los destinatarios previstos; pero desde luego no aparece en la muy cuidada y bien adaptada edición española. Podría ser este el mayor fallo que se podría achacar al libro, de no ser porque en cuanto se abren sus páginas se ve claro que está escrito pensando en jóvenes y adultos, por el tipo de explicaciones, el nivel de las mismas y las cuestiones que suscita.

Vale la pena detenerse siquiera brevemente en el prefacio, ya que desde sus primeras líneas se hace eco de una queja no siempre formulada,

\footnotetext{
${ }^{56}$ Salamanca 1983.
} 
ni verbalizada por los creyentes, pero que resulta muy real para los cristianos de los siglos XX-XXI:

«Para muchos, la fe cristiana es como un vetusto y venerable edificio con numerosas piezas [salas], escalinatas, pasillos y recovecos. ¡Es tan fácil perderse en su interior! Hay tantos artículos de fe, mandamientos y normas de conducta, que uno no sabe cuáles son importantes y cuáles tienen solo interés marginal. Hace falta orientación. Y la presente obra trata de darla».

Y realmente consigue lo que se propone, desde el momento mismo que clarifica muchas cosas con un esquema limpio, con un lenguaje sencillo y directo, con unas explicaciones breves y bien condensadas en aquello que es posible explicar, con una referencia fácil de unos pasajes a otros para completar las explicaciones sin necesidad de repetirlas. El propósito inicial de ayudar a distinguir lo importante de lo marginal en la presentación de la fe tiene unos evidentes ecos conciliares que evocan el importantísimo principio que se encuentra en el Decreto de ecumenismo, 11, y que dice:

«Al comparar las doctrinas, [los teólogos] han de recordar que existe un orden o 'jerarquía' de las verdades de la doctrina católica, puesto que es diversa su conexión con el fundamento de la fe cristiana».

El catecismo comentado cuida delicada e inteligentemente este principio, y lo lleva a la práctica, de manera que las explicaciones de cuanto es principal queda suficientemente expresado; $y$, al contrario, cuanto no es fundamental o resulta marginal ocupa un claro lugar secundario, que ayuda a clarificar la respectiva importancia de cada afirmación.

Esto se consigue inicialmente con un esquema claro, articulado en cuatro partes, cada una de las cuales está subdividida en tantos temas como parecen necesarios a los autores. Tales temas se subdividen igualmente en apartados, cuyo número varía en función de las necesidades del propio tema. El esquema es ágil, y cada uno de los apartados sobre los que se edifica la obra resulta igualmente ágil: la extensión de cada uno viene a ser la de una página, o incluso menos, lo que evita las divagaciones para ir directamente a centrarse en la cuestión propuesta.

Cada apartado está presentado de la siguiente forma: el epígrafe propio; una serie de referencias rápidas a otros lugares que pueden ser consultados, con una frase telegráfica que señala la idea principal a la que se 
remite, además del lugar preciso. A esto sigue un desarrollo o explicación, normalmente en varios párrafos no muy extensos, que utiliza con preferencias las frases cortas, directas y claras; unas complementan el pensamiento de las anteriores, y preparan para las explicaciones que siguen; están bien pensadas y bien ordenadas. Toda esta parte de explicación se destaca con un cuerpo de letra mayor que el que cerrará cada apartado, con explicaciones complementarias; este detalle - muy bien cuidadopermite percibir intuitivamente, sin necesidad de indicaciones, lo que es importante y lo que resulta secundario ${ }^{57}$.

Al término de la explicación de cada apartado se encuentra siempre un recuadro, tramado en color de fondo, que destaca una frase breve, una oración, una reflexión, un canto,...; es un elemento que introduce variedad y frescor por su origen variado, a la vez que una breve frase lo enlaza con la explicación que ha precedido. Estos recuadros actúan a modo de sencillas y fundamentales síntesis que rematan las explicaciones precedentes.

Tras cada recuadro, en letra menor que evidencia su menor importancia, aparecen otros conceptos relacionados con lo que ha constituido cada apartado; suelen estar explicados como breves definiciones, que además incluyen las aclaraciones precisas para situar cada concepto. Estas breves aclaraciones no suelen pasar de cinco líneas, aunque lo normal es que sean más breves, al estilo de la redacción directa con que está escrito el catecismo.

Si hasta aquí he descrito lo básico de la estructura y presentación de este catecismo, hay que dar un paso más, en consonancia con el objetivo de este estudio: analizar cómo se emplea la biblia en la presentación de la fe cristiana. Centrados en este preciso objetivo, no hay más remedio que señalar que todo él está transido de un estilo y un tono bíblico cuidado, acertado.

Puesto que el objetivo de la obra era ayudar a discernir lo importante de lo marginal, resulta imposible presentar lo importante sin remitir a la

${ }^{57}$ Otros catecismos han pretendido utilizar el mismo procedimiento. Pero un desmedido afán de proponer más y más cosas ha llevado a que las explicaciones secundarias resultaran excesivas en cantidad; también ha sucedido que se han reservado para lo secundario datos verdaderamente fundamentales, $\mathrm{y}$, al contrario, entre lo fundamental haya cuestiones que realmente no lo son. 
consulta de la biblia. No podía ser de otra manera, ni se podía buscar otro fundamento. Se acude a la palabra de Dios para cimentar la fe, la oración, el cumplimiento de los mandamientos, el estilo de vida cristiano. Las citas están cuidadas y seleccionadas con tino. Con ellas no se trata de apabullar con una cantidad exagerada de citas en aquellos temas o cuestiones muy desarrollados en la biblia (por ejemplo, la adoración a Dios, la eucaristía); se ha preferido no recurrir a la abundancia, en aras de la claridad y de la sólida cimentación de la fe. Las citas bíblicas son expresas en numerosas ocasiones, salvo cuando se hace una rápida referencia que puede ser consultada, pero que no interrumpe el discurso. Esta combinación de cantidad y calidad permite que el lector no se tope con un cúmulo de frases bíblicas que le desbordaría, y a la vez muestra con naturalidad que lo que se afirma y propone no es una compleja propuesta de sabios o teólogos, sino que el fundamento es la misma palabra de Dios que legitima las afirmaciones de la fe.

En estas condiciones en que se desarrolla la obra, es posible encontrar unos apartados que solo tienen una o dos citas bíblicas, junto a otros que llegan hasta la decena. El número desigual no constituye obstáculo para percibir que la palabra de Dios tiene carácter fundante en la presentación de la fe. La presencia constante de la biblia, el acompañamiento de cada explicación con el recurso a la escritura permiten ver claro que la biblia no constituye un simple apéndice ilustrativo, sino todo lo contrario. Y lo que se dice y enseña para fundamentar el constante recurso a la biblia, no tiene desperdicio:

«El cristianismo no es una religión que se base en un libro como autoridad suprema. El cristianismo se basa en una persona. Jesús de Nazaret es para los cristianos el testigo más fiel del amor de Dios. Ahora bien, todos los cristianos se guían por un libro, que es el documento de su fe: la Biblia. La Biblia es el testimonio de una larga historia de fe, una historia que se remonta hasta los comienzos de Israel como pueblo de Dios. Las sagradas Escrituras de Israel -los escritos del antiguo testamento, como los llamamos nosotros- son también normativos para los cristianos.

Los cristianos equipararon a esos escritos los documentos que atestiguan la fe de los discípulos de Jesús. Estos documentos constituyen las sagradas Escrituras de la nueva alianza» (p. 17).

Resulta patente una conclusión: que el empleo atinado de la biblia (bien seleccionado, oportuno, habitual) constituye la mejor forma de pre- 
sentar la fe cristiana. Esto no excluye las aclaraciones o las reflexiones adecuadas; pero en ningún momento constituyen un obstáculo para llegar a la palabra de Dios, sino que son la consecuencia lógica de tenerla muy en cuenta.

\subsection{Antonio Salas}

El año 1977 el agustino Antonio Salas asumió un reto que flotaba en el ambiente: el de redactar un catecismo para adultos. Y, dada su especialidad como biblista la obra que publicó lleva el título de Catecismo bíblico para adultos ${ }^{58}$. El título resulta absolutamente exacto, puesto que la presentación que hace de la fe cristiana -en la que están presentes casi todos los temas habituales- tiene un hondo sentido bíblico. El tono de las explicaciones así como la presentación, reclaman un público adulto, con un nivel de formación algo superior a la media; en ocasiones cabe señalar que las explicaciones que ofrecen, por el deseo de aquilatarlas, tienen una cierta dificultad para la lectura, y es preciso llevar a cabo una segunda lectura con calma.

Pero es más que evidente que lo que aparece es el sentir de que en toda la obra se trata de tomar el pulso a la biblia para deducir de ella cuáles pueden ser las afirmaciones, y el pensar y sentir de un cristiano de finales del siglo XX.

No se enreda en cuestiones sutiles derivadas de la exégesis, o susceptibles de ser entendidas como propuestas de uno u otro autor, a la hora de interpretar pasajes de la biblia. Lo que hace es tratar de presentar en cada ocasión cuál es lo nuclear que se desprende de la palabra de Dios, para que el creyente pueda fundamentar su fe en lo que la biblia transmite.

El que denomina como «catecismo» no es un catecismo al uso, a base de preguntas y respuestas, que despejan dudas y consolidan un saber. Lo que la obra pretende es hacer pensar, reflexionar, y, en consecuencia, cimentar la fe tras una seria consulta de la misma palabra de Dios. Abundan las citas bíblicas, como no podía ser de otra manera, pero no se acude a ella como si se tratara de una serie de afirmaciones que silenciaran las preguntas o acallaran la inquietud del hombre creyente, sino que son en-

\footnotetext{
58 A. Salas, Catecismo bíblico para adultos (Madrid 1979).
} 
tendidas como propuestas que incitan a pensar, con la ayuda y acompañamiento de la palabra misma de Dios.

He seleccionado dos pasajes que no citan más que en una sola ocasión texto bíblico alguno, pero que, sin embargo, están empapados de un genuino sentir sobre lo que la escritura dice al hombre de todos los tiempos, y que el autor pone en claro. El primero de ello se refiere a la importancia y a la actualidad de la palabra de Dios para el creyente, en el que realiza el desplazamiento desde la «palabra» a la «Palabra», centrándola hábilmente en Cristo:

«Por eso, desde el momento mismo en que se hizo presente la figura de Cristo, quedó cancelado por parte de Dios el proceso revelador. Pero es precisamente entonces cuando comienza a realizar el hombre un complicado e ininterrumpido esfuerzo, cuyo objetivo es adquirir un conocimiento cada vez más auténtico de las verdades que Dios se ha dignado desvelarle. Pues bien, siendo la misma "palabra" divina objeto de revelación, esta reivindica una fuerza y sonoridad infinitas. En consecuencia, jamás logrará el hombre agotar todas sus posibilidades. Esto justifica que los creyentes de todas las épocas acudan a Cristo en busca de respuestas, sin que estas (Dios es inagotable) excluyan que la búsqueda prosiga hasta el fin de los tiempos» (p. 44).

El segundo ejemplo propuesto ahonda en las consecuencias que se derivan de una fe pascual que no se limite a la mera enunciación de verdades conocidas, sino que pase al terreno de los convencimientos. Tras haber presentado lo que la biblia aporta acerca de la resurrección de Jesús, añade:

«El cristianismo comienza a existir desde el momento en que los hombres (apóstoles) apoyan su existencia en la vida del resucitado. Ello exige adherirse a él con un nexo de fe. El cristianismo se apoyó, pues, desde sus mismos orígenes en la fe pascual (...) El cristianismo no siempre ha comprendido cuánto debe a la resurrección de Cristo. Ha centrado su interés en la pasión y muerte, hasta tal punto que ha llegado a ignorar el evento pascual. Por supuesto que el sacrificio de Jesús en la cruz es capital para la fe cristiana. Sin embargo, el calvario solo carecería de fuerza para justificar la subsistencia del cristianismo. Así lo dice Pablo: "Si Cristo no hubiese resucitado vana sería nuestra fe" $(1$ Co. 15,14) (...) Nadie ignora, a este respecto, que las asambleas y familias cristianas suelen estar presididas por una imagen de Jesús clavado en la cruz. No es que tal costumbre 
pueda tildarse de equivocada. Pero, ¿acaso no sería mucho mejor colocar en el lugar de honor la figura de un Cristo resucitado? Jesús muerto es, sin duda, idéntico a Cristo resucitado. Mas nuestra fe debe apoyarse fundamentalmente en la resurrección» (p. 324-325).

Los ejemplos seleccionados muestran que una verdadera catequesis bíblica no consiste únicamente en la repetición maquinal de unos pasajes o textos entresacados de cualquiera de los libros bíblicos, sino que discurre sobre todo por la captación del sentido que la palabra de Dios transmite al hombre, con vistas a fundamentar su fe y su relación con Él.

\section{CONCLUSIÓN}

Cuanto ha aparecido en las páginas precedentes es una serie de muestras, más o menos representativas, de lo que ha acontecido en el uso de la biblia por parte de los catecismos. Refleja de una manera veraz lo que ha sucedido en el pasado, porque no se trataba de retorcer las cosas para mostrar la excepción en lugar de la norma habitual. Y cuando ha aparecido la excepción ha sido preciso hacerlo notar, porque es lo que se manifiesta de manera distinta del resto de los catecismos contemporáneos.

Si ha sucedido así en el pasado, no hay más remedio que preguntarse: ¿qué sucederá en el futuro?, ¿por dónde irán las tendencias?, ¿cuáles serán los acentos que aparecerán subrayados en los catecismos del porvenir? Parece que el logro de la incorporación de la biblia en los catecismos es una adquisición irrenunciable. Pero... en otras épocas estuvo incorporada a la catequesis, y por cierto bien incorporada; y sin embargo, se fue desdibujando su papel y su importancia hasta el punto de desaparecer. ¿Volverá a suceder lo mismo?

Los documentos más solemnes, desde el concilio para acá (Dei Verbum, Catechesi tradendae, Verbum Domini,...), afirman con nitidez y fuerza, con garra y convencimiento, que no es posible una catequesis que cimiente adecuadamente la vida cristiana sin el sustento ordinario de la palabra de Dios. Es de esperar y desear que las afirmaciones no caigan en el vacío, y se olviden. En ese caso, estaríamos de nuevo en una más de las inconsecuencias de la Iglesia, como sucedió ya. Nadie tendría que escandalizarse por esto; pero sí sería posible lamentarse de esto. 
No cabe duda que se ha dado un importante avance en la lectura, el conocimiento y la consulta de la biblia, y que, en consecuencia, la liturgia, los catecismos, la lectura personal, e incluso la teología han realizado grandes avances precisamente por esa actitud. El conocimiento, la veneración, la aceptación cordial de la palabra de Dios ha experimentado un avance nada desdeñable. Con el mismo convencimiento es preciso afirmar que aún queda mucho por hacer, que aún quedan muchas ocasiones de leer la palabra de Dios, y aún quedan muchas oportunidades para conocerla y para darla a conocer.

La formación de los catequistas, en este punto concreto, resulta mucho mejor que en el pasado, pero es claramente insuficiente. Es una formación ocasional, por contraste con un conocimiento sistemático y suficientemente completo; es una formación fragmentaria, que se queda reducida en muchas ocasiones solamente al nuevo testamento, y ni siquiera este está libre de lagunas y vacíos; además, es una formación temporal, en el sentido de ceñirse casi en exclusiva al momento de la realización de la catequesis así como su preparación, pero sin una prolongación en el estudio personal. No es la única laguna en la formación de catequistas, aunque sea la que ahora centra esta reflexión.

Suele ocurrir que el catequista acude a los pasajes bíblicos que le proporcionan los materiales que emplea para desarrollar su catequesis. Pero ahí aparece la limitación de los autores de materiales catequéticos, que no siempre facilitan un uso adecuado de la biblia. No se trata de que sea preciso aducir una gran cantidad de textos, como sugerencias; pero sí es factible ofrecer unos cuantos textos alternativos para que sea el catequista el que elija el más oportuno o el más adecuado. Es ocasiones, los autores de materiales han de cuidar algo tan básico como citar bien, para que sea posible la localización del texto, pues no siempre sucede así. Si junto a ello se ofrece un comentario orientador al texto o textos propuestos, se pueden estar dando pasos notables de una manera sencilla y eficaz. Por descontado, los autores de materiales catequéticos no se pueden permitir el tergiversar los textos bíblicos para hacerles decir lo que no dicen, o para subrayar un criterio o una opinión personal, respetable pero no siempre objetiva; pero también esto sucede, y podrían proponerse algunas muestras, que molestarían a quienes las han publicado. 
Sobre todo, se tendría que dar a entender de forma clara, evidente, y convencida, que en toda catequesis la palabra de Dios tiene un carácter de fuente de donde brotan todos nuestros convencimientos, todos nuestros conocimientos y todas nuestras seguridades de cristianos. Esto tanto si se presenta al principio, como al medio o al final de cada tema de catequesis y en el nivel que sea. Porque ese convencimiento es algo más que una moda pasajera, una estrategia para vender, o una procedimiento para amenizar la catequesis. Es el íntimo reflejo de quien, personal o comunitariamente, se pliega ante Dios para decirle: «Habla, Señor, que tu siervo escucha». Y asimismo es el íntimo reflejo de quien, en la catequesis no transmite sus palabras, sus ideas o sus criterios, -ni personales ni grupalessino quien remite más allá, más lejos, más alto, a la palabra y la voluntad que Dios ha expresado.

Es cierto que hay signos reales, no imaginarios, que invitan al optimismo en cuanto al empleo de la biblia en los catecismos y en la catequesis. La travesía de un desierto bíblico se podría dar por superada, sin pecar de ingenuidad. Sin embargo, ha dejado huellas y cicatrices (lectura literal, carencia de adaptación en el lenguaje, recursos a unos pocos textos selectos,...). No será siempre fácil superar estos defectos de una forma fácil ni rápida.

Pero es posible vislumbrar un futuro esperanzador.

\section{APÉNDICE}

\section{Examen del Catecismo de Gaspar Astete y sus vinculaciones con la Biblia}

\begin{tabular}{|l|l|}
\hline CATECismo DE Astete & TEXTO DE LA Biblia \\
\hline $\begin{array}{l}\text { P. ¿Sois cristiano? Respondo. Sí, por la } \\
\text { gracia de Dios. }\end{array}$ & $\begin{array}{l}\text { En Antioquía fue donde se empezó a lla- } \\
\text { mar a los discípulos «cristianos» (Hch } \\
11.26) \text {. Pero por la gracia de Dios, soy lo } \\
\text { que soy (1Cor 15, 10). }\end{array}$ \\
\hline $\begin{array}{l}\text { P. ¿Qué quiere decir cristiano? R. Hom- } \\
\text { bre de Cristo. }\end{array}$ & $\begin{array}{l}\text { Pero si es por cristiano que no se aver- } \\
\text { güence, sino que glorifique a Dios por lle- } \\
\text { var ese nombre (1Pe 4, 16). }\end{array}$ \\
\hline $\begin{array}{l}\text { P. ¿Cuál es la señal del cristiano? R. La } \\
\text { santa Cruz. }\end{array}$ & $\begin{array}{l}\text { Jamás presumo de algo que no sea la cruz } \\
\text { de nuestro Señor Jesucristo (Gal 6,14). }\end{array}$ \\
\hline
\end{tabular}




\begin{tabular}{|c|c|}
\hline $\begin{array}{l}\text { P. ¿Por qué? R. Porque es figura de } \\
\text { Cristo crucificado, que en ella nos redi- } \\
\text { mió. }\end{array}$ & $\begin{array}{l}\text { Se humilló a sí mismo, haciéndose obe- } \\
\text { diente hasta la muerte y una muerte de } \\
\text { cruz (Flp } 2,8) \text {. }\end{array}$ \\
\hline $\begin{array}{l}\text { P. Mostrad cómo. R. En el nombre del } \\
\text { Padre y del Hijo + y del Espíritu Santo. } \\
\text { Amén. }\end{array}$ & $\begin{array}{l}\text { Haced discípulos a todos los pueblos y } \\
\text { bautizadlos para consagrarlos al Padre, al } \\
\text { Hijo y al Espíritu Santo (Mt 28,19). }\end{array}$ \\
\hline $\begin{array}{l}\text { P. ¿Por qué tantas veces? R. Porque en } \\
\text { todo tiempo y lugar nuestros enemigos } \\
\text { nos combaten y persiguen. }\end{array}$ & $\begin{array}{l}\text { El diablo, vuestro enemigo, ronda como } \\
\text { león rugiente, buscando a quién devorar } \\
(1 \mathrm{Pe} 5,8) \text {. }\end{array}$ \\
\hline $\begin{array}{l}\text { P. ¿Qué enemigos son estos? R. El De- } \\
\text { monio, el Mundo y la Carne. }\end{array}$ & $\begin{array}{l}\text { El diablo, vuestro enemigo, ronda como } \\
\text { león rugiente, buscando a quién devorar } \\
(1 \mathrm{Pe} 5,8) \text {. Si el mundo os odia, recordad } \\
\text { que primero me ha odiado a mí (Jn } \\
15,18) \text {. Pero experimento en mí otra ley } \\
\text { que lucha contra el dictado de mi mente } \\
\text { y me encadena a la ley del pecado que } \\
\text { está en mí (Rom } 7,23) \text {. }\end{array}$ \\
\hline $\begin{array}{l}\text { P.Y vos, ¿para qué lo decís? R. Para con- } \\
\text { fesar esta fe que tenemos los cristianos. }\end{array}$ & $\begin{array}{l}\text { Estad siempre dispuestos a dar razón de } \\
\text { vuestra esperanza a todo el que os pida } \\
\text { explicaciones (1Pe } 3,15) \text {. }\end{array}$ \\
\hline $\begin{array}{l}\text { P. ¿Qué cosa es fe? R. Creer lo que no } \\
\text { vimos. }\end{array}$ & $\begin{array}{l}\text { La fe es el fundamento de lo que se es- } \\
\text { pera y la prueba de lo que no se ve (Heb } \\
11,1) \text {. }\end{array}$ \\
\hline $\begin{array}{l}\text { P. ¿Por qué lo creéis? R. Porque Dios } \\
\text { nuestro Señor así lo ha revelado y la } \\
\text { santa Madre Iglesia así nos lo enseña. }\end{array}$ & $\begin{array}{l}\text { Toda Escritura ha sido inspirada por Dios } \\
\text { y es útil para enseñar, para persuadir, } \\
\text { para reprender y para educar en la recti- } \\
\text { tud }(2 \text { Tim } 3,16) \text {. }\end{array}$ \\
\hline $\begin{array}{l}\text { P. ¿Para qué son los Artículos de la Fe? } \\
\text { R. Para dar noticia distinta de Dios nues- } \\
\text { tro Señor y de Jesucristo nuestro Reden- } \\
\text { tor. }\end{array}$ & $\begin{array}{l}\text { Timoteo acaba de llegar a nosotros desde } \\
\text { Tesalónica con buenas noticias sobre } \\
\text { vuestra fe y vuestro amor }(1 \text { Tes } 3,6) \text {. }\end{array}$ \\
\hline $\begin{array}{l}\text { P. La Santísima Trinidad, ¿quién es? R. } \\
\text { Es el mismo Dios Padre, Hijo y Espíritu } \\
\text { Santo, tres personas distintas y un solo } \\
\text { Dios verdadero. }\end{array}$ & $\begin{array}{l}\text { Haced discípulos a todos los pueblos y } \\
\text { bautizadlos para consagrarlos al Padre, al } \\
\text { Hijo y al Espíritu Santo. (Mt 28,19).La } \\
\text { gracia de Jesucristo el Señor, el amor de } \\
\text { Dios y la comunión en los dones del Es- } \\
\text { píritu Santo estén con todos vosotros } \\
(2 \text { Cor } 13,13) \text {. }\end{array}$ \\
\hline
\end{tabular}




\begin{tabular}{|c|c|}
\hline . ¿El Padre es Dios? R. Sí, Padre. & $\begin{array}{l}\text { Pablo, apóstol, (...) por designio de Jesu- } \\
\text { cristo y de Dios Padre }(\mathrm{Gal} 1,1) \text {. }\end{array}$ \\
\hline P. ¿El Hijo es Dios? R. Sí, Padre. & $\begin{array}{l}\text { «Te conjuro por Dios vivo: dinos si tú eres } \\
\text { el Mesías, el Hijo de Dios». Jesús le res- } \\
\text { pondió: «Tú lo has dicho» (Mt 26, 63-64). }\end{array}$ \\
\hline $\begin{array}{l}\text { P. ¿El Espíritu Santo es Dios? R. Sí, } \\
\text { Padre. }\end{array}$ & $\begin{array}{l}\text { El Espíritu Santo, a quien el Padre en- } \\
\text { viará en mi nombre, hará que recordéis lo } \\
\text { que yo os he enseñado (Jn 14,26). }\end{array}$ \\
\hline $\begin{array}{l}\text { P. ¿Son tres Dioses? R. No, sino un solo } \\
\text { Dios verdadero, como también un solo } \\
\text { Omnipotente, un solo Eterno y un solo } \\
\text { Señor. }\end{array}$ & $\begin{array}{l}\text { Sabemos que el ídolo no es nada en el } \\
\text { mundo y que no hay más que un Dios }(. .) \\
\text { para nosotros no hay más que un Dios, } \\
(1 \text { Cor } 8,4.6) \text {. }\end{array}$ \\
\hline P. ¿El Padre es el Hijo? R. No, Padre. & Yo y el Padre somos uno. (Jn 10,30). \\
\hline $\begin{array}{l}\text { P. ¿El Espíritu Santo es el Padre, o el } \\
\text { Hijo? R. No, Padre. }\end{array}$ & $\begin{array}{l}\text { El Espíritu Santo, a quien el Padre en- } \\
\text { viará en mi nombre, hará que recordéis lo } \\
\text { que yo os he enseñado (Jn. 14, 26). }\end{array}$ \\
\hline $\begin{array}{l}\text { P. ¿Cómo es Dios todopoderoso? R. Por- } \\
\text { que con solo su poder hace todo cuanto } \\
\text { quiere. }\end{array}$ & $\begin{array}{l}\text { Se le apareció el Señor y le dijo: «Yo soy } \\
\text { el Dios Poderoso» }(\text { Gn 17,1). }\end{array}$ \\
\hline $\begin{array}{l}\text { P. ¿Cómo es Criador? R. Porque todo lo } \\
\text { hizo de la nada. }\end{array}$ & $\begin{array}{l}\text { Dios hizo todo esto de la nada. (2Mac } 7 \text {, } \\
\text { 28). }\end{array}$ \\
\hline $\begin{array}{l}\text { P. ¿Cómo es Salvador? R. Porque da la } \\
\text { gracia y perdona los pecados. }\end{array}$ & $\begin{array}{l}\text { Decid a la ciudad de Sión: Mira, ya viene } \\
\text { tu salvador. (Is } 62,11) \text {. }\end{array}$ \\
\hline $\begin{array}{l}\text { P ¿Cómo es Glorificador? R. Porque da } \\
\text { la Gloria a quien persevera en su gracia. }\end{array}$ & $\begin{array}{l}\text { Jesús le contestó: «¿No te he dicho que, si } \\
\text { tienes fe, verás la gloria de Dios?» (Jn 11, } \\
\text { 40). }\end{array}$ \\
\hline $\begin{array}{l}\text { P. ¿Cuál de las tres Divinas Personas se } \\
\text { hizo Hombre? R. La segunda, que es el } \\
\text { Hijo. }\end{array}$ & $\begin{array}{l}\text { Concebirás y darás a luz un hijo, al cual } \\
\text { pondrás por nombre Jesús. Él será } \\
\text { grande, será llamado Hijo del Altísimo } \\
\text { (Lc 1, 31-32). Tanto amó Dios al mundo } \\
\text { que entregó a su Hijo único (Jn } 3,16) \text {. }\end{array}$ \\
\hline $\begin{array}{l}\text { P. ¿Pues quién? R. Solamente el Hijo, el } \\
\text { cual hecho Hombre se llama Jesucristo. }\end{array}$ & $\begin{array}{l}\text { Al cual pondrás por nombre Jesús (Lc. } 1 \text {, } \\
\text { 31). Al que José puso por nombre Jesús } \\
(\text { Mt. } 1,25) \text {. }\end{array}$ \\
\hline $\begin{array}{l}\text { P. Pues, según eso, ¿quién es Jesucristo? } \\
\text { R. Es el Hijo de Dios vivo, que se hizo } \\
\text { hombre por nos redimir y dar ejemplo de } \\
\text { vida. }\end{array}$ & $\begin{array}{l}\text { El Sumo Sacerdote le dijo: «Te conjuro } \\
\text { por Dios vivo: dinos si tú eres el Mesías, } \\
\text { el Hijo de Dios». Jesús le respondió: «Tú } \\
\text { lo has dicho; y además os digo que veréis }\end{array}$ \\
\hline
\end{tabular}




\begin{tabular}{|c|c|}
\hline & $\begin{array}{l}\text { al Hijo del hombre sentado a la diestra } \\
\text { del Todopoderoso, y que viene sobre las } \\
\text { nubes del cielo» (Mt 26, 63-64). }\end{array}$ \\
\hline P. ¿Qué quiere decir Jesús? R. Salvador. & $\begin{array}{l}\text { Le pondrás por nombre Jesús, porque él } \\
\text { salvará a su pueblo de los pecados (Mt } 1 \text {, } \\
\text { 21). }\end{array}$ \\
\hline P. ¿Qué quiere decir Cristo? R. Ungido. & $\begin{array}{l}\text { El Espíritu Santo le había revelado que } \\
\text { no moriría antes de ver al Mesías enviado } \\
\text { por el Señor }(\operatorname{Lc} 2,26) \text {. }\end{array}$ \\
\hline $\begin{array}{l}\text { P. ¿De qué fue ungido? R. De las gracias } \\
\text { y Dones del Espíritu Santo. }\end{array}$ & $\begin{array}{l}\text { Me refiero a Jesús de Nazaret a quien } \\
\text { Dios ungió con Espíritu Santo (Hch 10, } \\
\text { 38). }\end{array}$ \\
\hline $\begin{array}{l}\text { P. ¿Pues cómo se obró el misterio de su } \\
\text { Concepción? R. En las entrañas de la Vir- } \\
\text { gen María formó el Espíritu Santo de la } \\
\text { purísima sangre de esta Señora un Cuerpo } \\
\text { perfectísimo, crió de la nada un Alma y la } \\
\text { unió a aquel Cuerpo; y en el mismo ins- } \\
\text { tante a este Cuerpo y Alma se unió el Hijo } \\
\text { de Dios; y de esta suerte el que antes era } \\
\text { sólo Dios, sin dejar de serlo, quedó hecho } \\
\text { hombre. }\end{array}$ & $\begin{array}{l}\text { Al sexto mes Dios envió al ángel Gabriel } \\
\text { a una ciudad de Galilea llamada Nazaret, } \\
\text { a una joven prometida a un hombre lla- } \\
\text { mado José, de la estirpe de David; el } \\
\text { nombre de la joven era María (...) María } \\
\text { dijo: «Aquí está la esclava del Señor; que } \\
\text { me suceda según dices palabra» Y el } \\
\text { ángel la dejó. (Lc 1,26-38). }\end{array}$ \\
\hline $\begin{array}{l}\text { P. ¿Y cómo nació milagrosamente? } R \text {. Sa- } \\
\text { liendo del vientre de María SS. sin detri- } \\
\text { mento de su Virginidad, a la manera que } \\
\text { el rayo del Sol sale por un cristal sin rom- } \\
\text { perlo ni mancharlo. }\end{array}$ & $\begin{array}{l}\text { Y dio a luz a su hijo primogénito, le en- } \\
\text { volvió en pañales y le acostó en un pese- } \\
\text { bre }(\mathrm{Lc} 2,7) \text {. }\end{array}$ \\
\hline $\begin{array}{l}\text { P. ¿Por qué quiso morir muerte de Cruz? } \\
\text { R. Por librarnos del pecado y de la } \\
\text { muerte eterna.P. ¿Pues cómo incurrimos } \\
\text { en ella? R. Pecando nuestro primer Padre } \\
\text { Adán, en quien todos pecamos }\end{array}$ & $\begin{array}{l}\text { El Padre me ama, porque yo doy mi vida, } \\
\text { para tomarla de nuevo. Nadie tiene poder } \\
\text { para quitármela; soy yo quien la doy por } \\
\text { mi propia voluntad (Jn 10,17-18). }\end{array}$ \\
\hline $\begin{array}{l}\text { P.¿Qué entendéis por el Infierno a que } \\
\text { bajó Cristo nuestro Señor después de } \\
\text { muerto? R. No al lugar de los condenados, } \\
\text { sino al Limbo donde estaban los Justos. }\end{array}$ & $\begin{array}{l}\text { Fue entonces cuando proclamó el men- } \\
\text { saje a los espíritus encarcelados (1Pe } 3 \text {, } \\
\text { 19). }\end{array}$ \\
\hline $\begin{array}{l}\text { P. ¿Cómo resucitó al tercero día? R. Tor- } \\
\text { nando a juntar su cuerpo y alma gloriosa } \\
\text { para nunca más morir. }\end{array}$ & $\begin{array}{l}\text { Jesús resucitó en la madrugada del pri- } \\
\text { mer día de la semana }(\mathrm{Mc} 16,9) \text {. }\end{array}$ \\
\hline
\end{tabular}




\begin{tabular}{|c|c|}
\hline $\begin{array}{l}\text { P. ¿Cómo subió a los Cielos? R. Con su } \\
\text { propia virtud. }\end{array}$ & $\begin{array}{l}\text { Después de hablarles, el Señor Jesús fue } \\
\text { elevado al cielo }(\text { Mc 16,19). Mientras los } \\
\text { bendecía, se separó de ellos y fue llevado } \\
\text { al cielo }(\text { Lc 24,51). }\end{array}$ \\
\hline $\begin{array}{l}\text { P. ¿Qué es estar sentado a la diestra de } \\
\text { Dios Padre? R. Tener igual gloria con Él } \\
\text { en cuanto Dios, y mayor que otro nin- } \\
\text { guno en cuanto hombre. }\end{array}$ & $\begin{array}{l}\text { Ascendido al cielo, está a la derecha de } \\
\text { Dios }(1 \mathrm{Pe} 3,22) .\end{array}$ \\
\hline $\begin{array}{l}\text { P. ¿Cuándo vendrá a juzgar los vivos y los } \\
\text { muertos? R. Al fin del mundo. }\end{array}$ & $\begin{array}{l}\text { Cuando venga el Hijo del hombre en su } \\
\text { gloria con todos sus ángeles,... (Mt 25, } \\
\text { 31ss). }\end{array}$ \\
\hline $\begin{array}{l}\text { P.¿Y entonces han de resucitar todos los } \\
\text { muertos? R. Sí, Padre, con los mismos } \\
\text { cuerpos y almas que tuvieron. }\end{array}$ & $\begin{array}{l}\text { Llegará el momento en que todos los } \\
\text { muertos oirán su voz y saldrán de los se- } \\
\text { pulcros (Jn 5, 28-29). }\end{array}$ \\
\hline $\begin{array}{l}\text { P. ¿Quién es la Iglesia? R. La Congrega- } \\
\text { ción de los Fieles Cristianos, cuya cabeza } \\
\text { es el Papa. }\end{array}$ & $\begin{array}{l}\text { Sobre esta piedra edificaré mi Iglesia (Mt } \\
16,18) .\end{array}$ \\
\hline $\begin{array}{l}\text { P. Además del Credo y los Artículos, ¿cre- } \\
\text { éis otras cosas? R. Sí, Padre, todo lo que } \\
\text { está en la Sagrada Escritura y cuanto } \\
\text { Dios tiene revelado a su Iglesia. }\end{array}$ & $\begin{array}{l}\text { Toda Escritura ha sido inspirada por Dios } \\
\text { y es útil para enseñar, para persuadir, } \\
\text { para reprender y para educar en la recti- } \\
\text { tud }(2 \text { Tim } 3,16) \text {. }\end{array}$ \\
\hline $\begin{array}{l}\text { P. Decid ¿quién dijo el Padre Nuestro? } \\
\text { R. Jesucristo. }\end{array}$ & $\begin{array}{l}\text { Jesús les dijo: «Cuando oréis, decid: } \\
\text { Padre, santificado sea tu Nombre, venga } \\
\text { tu reino... (Lc 11,2-4). }\end{array}$ \\
\hline P. ¿Para qué? R. Para enseñarnos a orar. & $\begin{array}{l}\text { Un día estaba Jesús orando en cierto } \\
\text { lugar. Cuando acabó, uno de sus discípu- } \\
\text { los le dijo: «Señor, ensénanos a orar, } \\
\text { como Juan enseñó a sus discípulos» (Lc } \\
\text { 11,1). }\end{array}$ \\
\hline $\begin{array}{l}\text { P. ¿Quién dijo el Ave María? R. El Ar- } \\
\text { cángel San Gabriel, cuando vino a salu- } \\
\text { dar a nuestra Señora la Virgen María. }\end{array}$ & $\begin{array}{l}\text { El ángel le dijo: «Dios te salve, llena de } \\
\text { gracia, el Señor está contigo» }(\text { Lc 1,28). }\end{array}$ \\
\hline $\begin{array}{l}\text { P. ¿Luego vos Ángel tenéis que os } \\
\text { guarde? R. Sí tengo, y cada uno de los } \\
\text { hombres tiene el suyo. }\end{array}$ & $\begin{array}{l}\text { Os digo que sus ángeles en el cielo con- } \\
\text { templan sin cesar el rostro de mi Padre } \\
(\mathrm{Mt} 18,10) \text {. }\end{array}$ \\
\hline $\begin{array}{l}\text { P. Decid, ¿cuál es el primer Manda- } \\
\text { miento de la Ley de Dios? R. Amar a } \\
\text { Dios sobre todas las cosas. }\end{array}$ & $\begin{array}{l}\text { Yo soy el Señor, tu Dios, el que te sacó de } \\
\text { Egipto, de aquel lugar de esclavitud (Ex } \\
20,3) \text {. }\end{array}$ \\
\hline
\end{tabular}




\begin{tabular}{|c|c|}
\hline $\begin{array}{l}\text { P. ¿Quién ama a Dios? R. El que guarda } \\
\text { sus Mandamientos. }\end{array}$ & $\begin{array}{l}\text { El que acepta mis preceptos y los pone en } \\
\text { practica, ése me ama de verdad (Jn 14, } \\
21 \text { ). }\end{array}$ \\
\hline $\begin{array}{l}\text { P. ¿A qué más nos obliga este Manda- } \\
\text { miento? R. A adorarle a él solo con suma } \\
\text { reverencia de cuerpo y alma, creyendo y } \\
\text { esperando en él con Fe viva. }\end{array}$ & $\begin{array}{l}\text { ¿Acaso algún pueblo cambia de dioses?, } \\
\text {-y eso que no son dioses- }(\operatorname{Jr} 2,11) .\end{array}$ \\
\hline $\begin{array}{l}\text { P. ¿Quién peca contra esto? R. El que } \\
\text { adora o cree en Ídolos o Dioses falsos; }\end{array}$ & $\begin{array}{l}\text { No tendrás para ti otros dioses fuera de } \\
\text { mí (Ex 20,3). }\end{array}$ \\
\hline $\begin{array}{l}\text { P. ¿Cuál es el segundo? R. No jurar su } \\
\text { Santo Nombre en vano. }\end{array}$ & $\begin{array}{l}\text { No tomarás en vano el nombre del Señor } \\
\text { (Ex 20,7). También habéis oído que se } \\
\text { dijo a nuestros antepasados: No jurarás } \\
\text { en falso, sino que cumplirás lo que pro- } \\
\text { metiste al Señor (Mt } 5,33 \text { ). }\end{array}$ \\
\hline $\begin{array}{l}\text { P. ¿Quién se dice jurar en vano? R. El } \\
\text { que jura sin verdad, sin justicia o sin ne- } \\
\text { cesidad. }\end{array}$ & $\begin{array}{l}\text { Jurarás: «¡Por vida de Yahveh!» con ver- } \\
\text { dad, con derecho y con justicia }(\mathrm{Jr} 4,2) \text {. }\end{array}$ \\
\hline $\begin{array}{l}\text { P. ¿Y el que jura o hace voto o promesa de } \\
\text { hacer alguna cosa buena está obligado a } \\
\text { cumplirla? R. Sí, Padre, y el no cumplirla } \\
\text { o dilatarla notablemente, [...] es pecado } \\
\text { mortal siendo la materia grave. }\end{array}$ & $\begin{array}{l}\text { Cuando hagas una promesa a Dios no } \\
\text { tardes en cumplirla, porque no le agradan } \\
\text { los necios; lo que prometas, cúmplelo. } \\
\text { Mejor es no hacer promesas que hacerlas } \\
\text { y no cumplirlas (Eclo 5,3-4). }\end{array}$ \\
\hline $\begin{array}{l}\text { P. ¿Qué remedio hay para no jurar en } \\
\text { vano? R. Acostumbrarse a decir sí o no } \\
\text { como Cristo nos enseña. }\end{array}$ & $\begin{array}{l}\text { Que vuestra palabra sea sí, cuando es sí; } \\
\text { y no, cuando es no (Mt } 5,37) \text {. }\end{array}$ \\
\hline $\begin{array}{l}\text { P. ¿Y se prohíbe alguna cosa más en este } \\
\text { mandamiento? R. Sí, Padre, se prohíbe } \\
\text { también la blasfemia, que es decir pala- } \\
\text { bras injuriosas contra Dios o sus Santos, } \\
\text { lo que es pecado mortal. }\end{array}$ & $\begin{array}{l}\text { Saca al blasfemo del campamento (Lv 24, } \\
\text { 14). }\end{array}$ \\
\hline $\begin{array}{l}\text { P. ¿Cuál es el tercero? R. Santificar las } \\
\text { Fiestas. }\end{array}$ & $\begin{array}{l}\text { Acuérdate del sábado para santificarlo } \\
(\text { Ex 20,8). }\end{array}$ \\
\hline $\begin{array}{l}\text { P. ¿Cuál es el cuarto? R. Honrar Padre y } \\
\text { Madre. }\end{array}$ & $\begin{array}{l}\text { Honra a tu padre y a tu madre (Ex. } 20 . \\
12 \text { ). }\end{array}$ \\
\hline $\begin{array}{l}\text { P. ¿Quiénes pecan mortalmente contra } \\
\text { esto? R. Los hijos que no obedecen a sus } \\
\text { Padres en las cosas tocantes al gobierno } \\
\text { de la casa y buenas costumbres; los que no } \\
\text { los socorren en sus necesidades; }\end{array}$ & $\begin{array}{l}\text { Pero vosotros decís: El que diga a su padre } \\
\text { o a su madre: «He ofrecido a Dios los bienes } \\
\text { con los que te podía ayudar», no tiene obli- } \\
\text { gación de socorrer a su padre. Así anuláis el } \\
\text { mandamiento de Dios (Mt } 15,5-6 \text { ). }\end{array}$ \\
\hline
\end{tabular}




\begin{tabular}{|c|c|}
\hline P. ¿Cuál es el quinto? R. No matar. & No matarás (Ex 20,13). \\
\hline P. ¿Cuál es el sexto? R. No fornicar. & No cometerás adulterio (Ex 20,14). \\
\hline P. ¿Cuál es el séptimo? R. No hurtar. & No robarás (Ex 20 15). \\
\hline $\begin{array}{l}\text { P. ¿Cuál es el octavo? R. No levantar } \\
\text { falso testimonio ni mentir. }\end{array}$ & $\begin{array}{l}\text { No darás falso testimonio contra tu pró- } \\
\text { jimo (Ex 20,16). }\end{array}$ \\
\hline $\begin{array}{l}\text { [P. ¿Cuál es el noveno? R. No desear la } \\
\text { mujer de tu prójimo]. }\end{array}$ & $\begin{array}{l}\text { Ni codiciarás la mujer de tu prójimo (Ex. } \\
20,17) .\end{array}$ \\
\hline $\begin{array}{l}\text { [P. Cuáles el décimo? R. No codiciar los } \\
\text { bienes ajenos]. }\end{array}$ & $\begin{array}{l}\text { No codiciarás la casa de tu prójimo (...) ni } \\
\text { su siervo, ni su sierva, ni su buey, ni su } \\
\text { asno, ni nada de lo que le pertenezca (Ex } \\
20,17) \text {. }\end{array}$ \\
\hline $\begin{array}{l}\text { La segunda, dar de comer al ham- } \\
\text { briento... }\end{array}$ & $\begin{array}{l}\text { Porque tuve hambre, y me disteis de } \\
\text { comer; tuve sed, y me disteis de beber... } \\
\text { (Mt } 25,35) \text {. }\end{array}$ \\
\hline $\begin{array}{l}\text { P. ¿Por qué se llaman de misericordia? R. } \\
\text { Porque no se deben de justicia. }\end{array}$ & $\begin{array}{l}\text { Daba mis alimentos a los tenían hambre } \\
\text { y mis ropas a los que estaban desnudos } \\
\text { (Tob } 1,17) \text {. }\end{array}$ \\
\hline $\begin{array}{l}\text { P. ¿Cuándo obligan de precepto? R. En } \\
\text { necesidades que a juicio de hombres dis- } \\
\text { cretos sean graves. }\end{array}$ & $\begin{array}{l}\text { Si alguno que tiene bienes de este mundo } \\
\text { ve a su hermano en necesidad y no se } \\
\text { apiada de él, ¿cómo puede permanecer } \\
\text { en él el amor de Dios? Hijos míos, no } \\
\text { amemos de palabra ni con la boca, sino } \\
\text { con hechos y de verdad ( } 1 \mathrm{Jn} 3,16) \text {. }\end{array}$ \\
\hline $\begin{array}{l}\text { P. ¿Qué cosa es Fe? R. Creer lo que no } \\
\text { vimos, porque Dios lo ha revelado. }\end{array}$ & $\begin{array}{l}\text { La fe es el fundamento de lo que se es- } \\
\text { pera y la prueba de lo que no se ve (Hb. } \\
11,1) \text {. }\end{array}$ \\
\hline $\begin{array}{l}\text { P. ¿Qué cosa es Esperanza? R. Esperar } \\
\text { la gloria, mediante la gracia de Dios y } \\
\text { nuestras buenas obras. }\end{array}$ & $\begin{array}{l}\text { Porque ya estamos salvados, aunque sólo } \\
\text { en esperanza; y es claro que la esperanza } \\
\text { que se ve, no es propiamente esperanza } \\
(\text { Rom } 8,24) \text {. }\end{array}$ \\
\hline $\begin{array}{l}\text { P. ¿Qué cosa es Caridad? R. Amar a Dios } \\
\text { sobre todas las cosas, y a nuestros próji- } \\
\text { mos como a nosotros mismos, habiéndo- } \\
\text { nos con ellos como quisiéramos que se } \\
\text { hubiesen con nosotros. }\end{array}$ & $\begin{array}{l}\text { Él le contestó: «Amarás al Señor, tu Dios, } \\
\text { con todo tu corazón, con toda tu alma y } \\
\text { con toda tu mente. Este es el primer man- } \\
\text { damiento y es el más importante. El se- } \\
\text { gundo es semejante a éste: Amarás a tu } \\
\text { prójimo como a ti mismo (Mt 22,37-39). }\end{array}$ \\
\hline
\end{tabular}




\begin{tabular}{|c|c|}
\hline $\begin{array}{l}\text { P. ¿Qué es pecado original? R. Aquel con } \\
\text { que todos nacemos heredado de nuestros } \\
\text { primeros padres. }\end{array}$ & $\begin{array}{l}\text { Por un hombre entró el pecado en el } \\
\text { mundo y con el pecado la muerte. Y como } \\
\text { todos los hombres pecaron, a todos les al- } \\
\text { canzó la muerte (Rom 5,12). }\end{array}$ \\
\hline $\begin{array}{l}\text { P. ¿Para qué es el Sacramento de la Con- } \\
\text { firmación? R. Para confirmarnos y forta- } \\
\text { lecernos la Fe que recibimos en el } \\
\text { Bautismo. }\end{array}$ & $\begin{array}{l}\text { Estos bajaron y oraron por ellos para que } \\
\text { recibieran el Espíritu Santo (Hch 8,15). }\end{array}$ \\
\hline $\begin{array}{l}\text { P. ¿Para qué es el Sacramento de la Peni- } \\
\text { tencia? R. Para perdonar los pecados co- } \\
\text { metidos después del Bautismo. }\end{array}$ & $\begin{array}{l}\text { A quienes perdonéis los pecados, Dios se } \\
\text { los perdonará }(\mathrm{Jn} 20,23) .\end{array}$ \\
\hline $\begin{array}{l}\text { P. ¿Para qué es el Santísimo Sacramento } \\
\text { de la Comunión? } R \text { Para que, recibién- } \\
\text { dole dignamente, sea mantenimiento de } \\
\text { nuestras almas y nos aumente la gracia. }\end{array}$ & $\begin{array}{l}\text { Mientras cenaban, Jesús tomó pan, pro- } \\
\text { nunció la bendición, lo partió y, se lo dio } \\
\text { a sus discípulos, diciendo: «Tomad y } \\
\text { comed: esto es mi cuerpo». Tomó luego } \\
\text { una copa y, después de dar gracias, se la } \\
\text { dio diciendo: «Bebed todos de ella» (Mt } \\
\text { 26, 26-27). }\end{array}$ \\
\hline 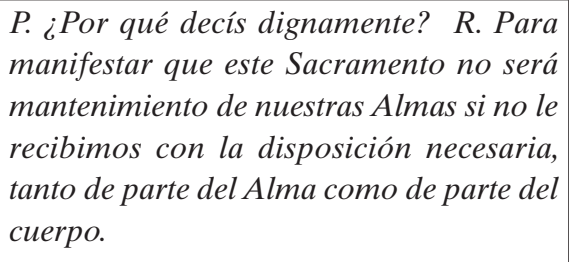 & $\begin{array}{l}\text { Por eso, quien coma el pan o beba el cáliz } \\
\text { del Señor indignamente, se hace culpable } \\
\text { de profanar el Cuerpo del Señor (1Cor } \\
11,27) \text {. }\end{array}$ \\
\hline $\begin{array}{l}\text { P. ¿Y el que llega a la comunión, sin las } \\
\text { disposiciones dichas, recibe también a Je- } \\
\text { sucristo? R. Si, P., mas sin provecho al- } \\
\text { guno, porque comete un gravísimo } \\
\text { pecado. }\end{array}$ & $\begin{array}{l}\text { Por eso, quien coma el pan o beba el cáliz } \\
\text { del Señor indignamente, se hace culpable } \\
\text { de profanar el Cuerpo del Señor (1Cor } \\
11,27) \text {. }\end{array}$ \\
\hline $\begin{array}{l}\text { P. ¿Para qué es el Sacramento de la Ex- } \\
\text { trema Unción? R. Para tres cosas. } \\
\text { P. ¿Cuáles son? R. La primera, para qui- } \\
\text { tar los rastros y reliquias de la mala vida } \\
\text { pasada. } \\
\text { La segunda, para dar esfuerzo al alma } \\
\text { contra las tentaciones del demonio. } \\
\text { La tercera, para dar salud al cuerpo, si le } \\
\text { conviene. }\end{array}$ & $\begin{array}{l}\text { Si alguno de vosotros cae enfermo, que } \\
\text { llame a los presbíteros de la Iglesia, para } \\
\text { que oren sobre él y le unjan con óleo en } \\
\text { nombre del Señor. Y la oración hecha con } \\
\text { fe salvará al enfermo, el Señor lo resta- } \\
\text { blecerá, y le serán perdonados que hu- } \\
\text { biera cometido (Sant 5,14-15). }\end{array}$ \\
\hline
\end{tabular}




\begin{tabular}{|c|c|}
\hline $\begin{array}{l}\text { La primera, Prudencia. } \\
\text { La segunda, Justicia. } \\
\text { La tercera, Fortaleza. } \\
\text { La cuarta, Templanza. }\end{array}$ & $\begin{array}{l}\text { A quien ama la justicia de da como fruto } \\
\text { las virtudes, porque enseña templanza y } \\
\text { prudencia, justicia y fortaleza ( } \operatorname{Sab} 8,7) \text {. }\end{array}$ \\
\hline $\begin{array}{l}\text { El primero, Don de Sabiduría. } \\
\text { El segundo, Don de Entendimiento. } \\
\text { El tercero, Don de Consejo. } \\
\text { El cuarto, Don de Ciencia. } \\
\text { El quinto, Don de Fortaleza. } \\
\text { El sexto, Don de Piedad. } \\
\text { El séptimo, Don de Temor de Dios. }\end{array}$ & $\begin{array}{l}\text { Sobre él reposará el espíritu del Señor, } \\
\text { espíritu de inteligencia y sabiduría, espí- } \\
\text { ritu de consejo y valor, espíritu de cono- } \\
\text { cimiento y temor del Señor (Is } 11,2 \text { ). }\end{array}$ \\
\hline $\begin{array}{l}\text { El primero, Caridad. } \\
\text { El segundo, Paz. } \\
\text { El tercero, Longanimidad. } \\
\text { El cuarto, Benignidad. } \\
\text { El quinto, Fe. } \\
\text { El sexto, Continencia. } \\
\text { El séptimo, Gozo. } \\
\text { El octavo, Paciencia. } \\
\text { El nono, Bondad. } \\
\text { El décimo, Mansedumbre. } \\
\text { El undécimo, Modestia. } \\
\text { El duodécimo, Castidad. }\end{array}$ & $\begin{array}{l}\text { En cambio, los frutos del Espíritu son: } \\
\text { amor, alegría, paz, tolerancia, amabilidad, } \\
\text { bondad, fe, mansedumbre y dominio de sí } \\
(\text { Gal 5, 22-23). }\end{array}$ \\
\hline $\begin{array}{l}\text { Bienaventurados los pobres de Espíritu, } \\
\text { porque de ellos es el Reino de los Cielos. } \\
\text { Bienaventurados los mansos, porque } \\
\text { ellos poseerán la tierra. } \\
\text { Bienaventurados los que lloran, porque } \\
\text { ellos serán consolados. } \\
\text { Bienaventurados los que han hambre y } \\
\text { sed de la Justicia, porque ellos serán har- } \\
\text { tos. } \\
\text { Bienaventurados los misericordiosos, } \\
\text { porque ellos alcanzarán misericordia. } \\
\text { Bienaventurados los limpios de corazón, } \\
\text { porque ellos verán a Dios. } \\
\text { Bienaventurados los pacíficos, porque } \\
\text { ellos serán llamados hijos de Dios. } \\
\text { Bienaventurados los que padecen perse- } \\
\text { cución por la Justicia, porque de ellos será } \\
\text { el Reino de los Cielos. }\end{array}$ & $\begin{array}{l}\text { Dichosos los pobres en el espíritu, porque } \\
\text { suyo es el reino de los Cielos. } \\
\text { Dichosos los que están tristes, porque } \\
\text { Dios los consolará. } \\
\text { Dichosos los humildes, porque heredarán } \\
\text { la tierra. } \\
\text { Dichosos los que tienen hambre y sed de } \\
\text { hacer la voluntad de Dios, porque Dios } \\
\text { los saciará. } \\
\text { Dichosos los misericordiosos, porque } \\
\text { Dios tendrá misericordia de ellos. } \\
\text { Dichosos los que tienen un corazón lim- } \\
\text { pio, porque ellos verán a Dios. } \\
\text { Dichosos los que construyen la paz, por- } \\
\text { que ellos serán llamados hijos de Dios. } \\
\text { Dichosos los perseguidos por hacer la vo- } \\
\text { luntad de Dios, porque de ellos es el reino } \\
\text { de los cielos (Mt } 5,3-10 \text { ). }\end{array}$ \\
\hline
\end{tabular}

